\begin{tabular}{|c|c|c|c|c|c|c|}
\hline \multirow{4}{*}{ Impact Factor: } & ISRA (India) & $=3.117$ & SIS (USA) & $=0.912$ & ICV (Poland) & $=6.630$ \\
\hline & ISI (Dubai, UAE & $=0.829$ & РИНЦ (Russia) & $=0.156$ & PIF (India) & $=1.940$ \\
\hline & GIF (Australia) & $=0.564$ & ESJI (KZ) & $=8.716$ & IBI (India) & $=4.260$ \\
\hline & JIF & $=1.500$ & SJIF (Morocco) & $=5.667$ & OAJI (USA) & $=0.350$ \\
\hline
\end{tabular}

\begin{tabular}{|c|c|}
\hline $\begin{array}{l}\text { SOI: } \underline{1.1 / \mathrm{T}} \\
\text { International Sc} \\
\text { Theoretical } \boldsymbol{\&}\end{array}$ & $\begin{array}{l}\frac{\mathrm{AS}}{\mathrm{DOI}} \mathrm{10.15863/ \textrm {TAS }} \\
\text { ientific Journal } \\
\text { Applied Science }\end{array}$ \\
\hline p-ISSN: 2308-4944 (print) & e-ISSN: 2409-0085 (online) \\
\hline Year: 2019 Issue: 02 & Volume: 70 \\
\hline Published: 13.02 .2019 & http://T-Science.org \\
\hline
\end{tabular}

UDC 335. 47 519. 74.

SECTION 31. Economic research, finance, innovation, risk management.

$$
\text { QR - Issue }
$$

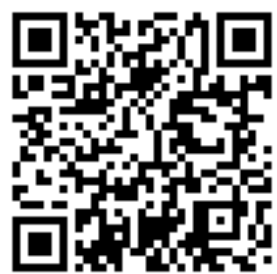

QR - Article

Artur Alexandrovich Blagorodov bachelor, Department of "Design, technology, and design" Institute of service sector and entrepreneurship (branch) of DSTU in Shakhty, Rostov region bordux1995@icloud.com

Dmitry Olegovich Bordukh bachelor, Department of "Design, technology, and design" Institute of service sector and entrepreneurship (branch) of DSTU in Shakhty, Rostov region bordux1995@icloud.com

Angelina Vladimirovna Kopylova bachelor, Department of "Design, technology, and design" Institute of service sector and entrepreneurship (branch) of DSTU in Shakhty, Rostov region prohorov@sssu.ru

Daria Sergeevna Smolina bachelor, Department of "Design, technology, and design" Institute of service sector and entrepreneurship (branch) of DSTU in Shakhty, Rostov region prohorov@sssu.ru

Vladimir Timofeevich Prokhorov Doctor of technical sciences, professor, Professor the department "Designing, technology and design", ISOP (f) DGTU, Shakhty prohorov@sssu.ru

Yuri Dmitrievich Mishin candidate of philosophy, Professor, Department of Philosophy and Culturology "Siberian state University of railway communication" Novosibirsk vinichenkoan@stu.ru

\title{
COMPARATIVE ANALYSIS OF ECONOMIC THEORIES FOR THEIR EFFECTIVE MANAGEMENT TEAM OF THE COMPANY FOR DEFECT-FREE DIGITAL PRODUCTION OF IMPORT-SUBSTITUTING PRODUCTS TO CONSUMERS OF THE SOUTHERN FEDERAL DISTRICT AND SKFO. (1 MESSAGE)
}

Abstract: in the article the authors analyze the possibilities of policy and objectives in the field of quality in the framework of (QMS) for machine-building enterprises on the basis of "JSC LMC" "plant "Techmash"" "LLC" Dontex "and" LLC Metalstroy " that would fight for a defect-free production, making popular and importsubstituting products, to fight for the reduction of marriage and to guarantee consumers high quality products. The use of statistical methods of quality control ( using the Pareto chart tool) to ensure the production of import- 


\begin{tabular}{|c|c|c|c|c|c|c|}
\hline \multirow{4}{*}{ Impact Factor: } & ISRA (India) & $=3.117$ & SIS (USA) & $=0.912$ & ICV (Poland) & $=6.630$ \\
\hline & ISI (Dubai, UAE & $=\mathbf{0 . 8 2 9}$ & РИНЦ (Russia & $=0.156$ & PIF (India) & $=1.940$ \\
\hline & GIF (Australia) & $=0.564$ & ESJI (KZ) & $=8.716$ & IBI (India) & $=4.260$ \\
\hline & JIF & $=1.500$ & SJIF (Morocco & $=5.667$ & OAJI (USA) & $=0.350$ \\
\hline
\end{tabular}

substituting products. The use of Pareto diagram allowed the authors to visualize the results of the efforts of the company's managers within the QMS to provide them with faultless and waste-free production with a significant reduction in the output of defective products.

Key words: QMS, certification, import substitution, demanded, conformity assessment, standardization, audit, demand, defective products, Pareto chart, quality policy and objectives, documentation, effectiveness, efficiency, responsibility.

Language: Russian

Citation: Blagorodov, A. A., Bordukh, D. O., Kopylova, A. V., Smolina, D. S., Prokhorov, V. T., \& Mishin, Y. D. (2019). Comparative analysis of economic theories for their effective management team of the company for defect-free digital production of import-substituting products to consumers of the Southern federal district and SKFO. (1 message). ISJ Theoretical \& Applied Science, 02 (70), 41-79.

Soi: http://s-o-i.org/1.1/TAS-02-70-8 Doi: crossef https://dx.doi.org/10.15863/TAS.2019.02.70.8

\section{СРАВНИТЕЛЬНЫЙ АНАЛИЗ ЭКОНОМИЧЕСКИХ ТЕОРИЙ НА ПРЕДМЕТ ИХ ЭФФЕКТИВНОГО УПРАВЛЕНИЯ КОЛЛЕКТИВОМ ПРЕДПРИЯТИЯ ДЛЯ БЕЗДЕФЕКТНОГО ЦИФРОВОГО ПРОИЗВОДСТВА ИМПОРТОЗАМЕЩАЕМОЙ ПРОДУКЦИИ ПОТРЕБИТЕЛЯМ ЮФО И СКФО. (СООБЩЕНИЕ 1)}

Аннотация: в сообщении 1 авторы анализируют возможности политики и иели в области качества в рамках (СМК) для машиностроительных предприятий на базе ОАО «НЛМК» ООО завод «Техмаш» ООО «Дон - Текс» и ООО «Металл-строй», чтобы бороться за бездефектное производства, изготавливая востребованную и импортозамещзаемую продукцию, бороться за снижение брака и гарантировать потребителям высокое качество изготавливаемой продукиии. Применение статистических методов контроля качества, (с использованием инструмента - диаграммы Парето) с иелью обеспечения производства импортозамещчаемой продукиии. Использование диаграммы Парето позволили авторам наглядно представить результаты усилий руководителей предприятия в рамках СМК обеспечивать им бездефектное и безотходное производство с существенным снижением выпуска бракованной продукции.

Ключевые слова: СМК, сертификация, импортозамещение, востребованное, подтверждение соответствия, стандартизация, аудит, спрос, бракованная продукция, диаграмма Парето, политика и цели качества, документация, результативность, эффективность, ответственность,

\section{Введение}

Процесс принятия управленческих решений. Принятие решений в управлении представляет собой сложный и систематизированный процесс, состоящий из ряда этапов и стадий, начинающийся с формулирования проблемы и заканчивающийся совершением действий, решающих эту проблему (рисунок 1).

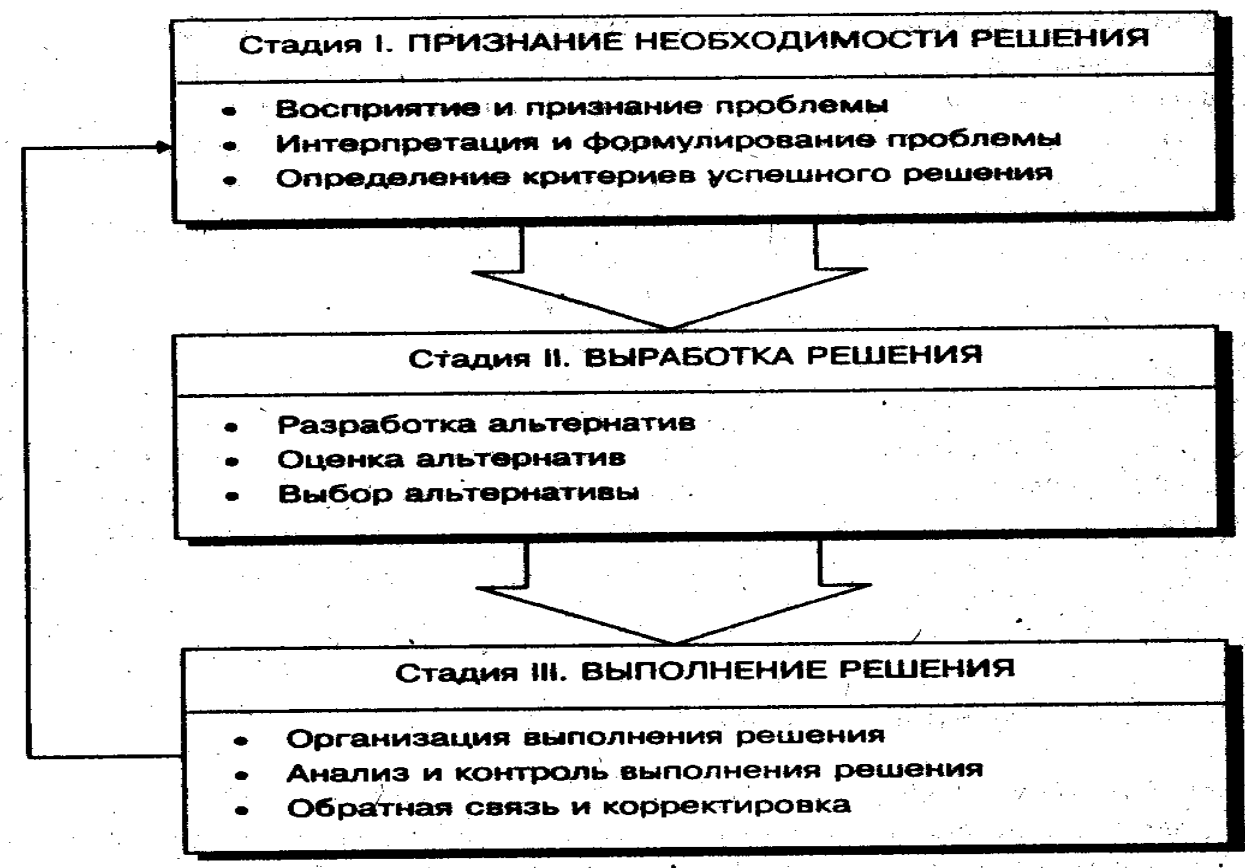

Рис 1. Процесс принятия решения. 


\begin{tabular}{|c|c|c|c|c|c|c|}
\hline \multirow{4}{*}{ Impact Factor: } & ISRA (India) & $=3.117$ & SIS (USA) & $=0.912$ & ICV (Poland) & $=6.630$ \\
\hline & ISI (Dubai, UAE & $=0.829$ & РИНЦ (Russia) & $=0.156$ & PIF (India) & $=1.940$ \\
\hline & GIF (Australia) & $=0.564$ & ESJI $(\mathrm{KZ})$ & $=8.716$ & IBI (India) & $=4.260$ \\
\hline & JIF & $=1.500$ & SJIF (Morocco) & $=5.667$ & OAJI (USA) & $=0.350$ \\
\hline
\end{tabular}

Первая стадия рассматриваемого процесса состоит в признании необходимости решения и включает в себя следующие этапы:

- $\quad$ признание проблемы;

-

- определение критериев успешного решения проблемы.

Процесс протекает по-разному для структурированных и неструктурированных проблем (рисунок 2). В первом случае признание проблемы будет происходить достаточно прямолинейно. Во втором случае признание проблемы само становится проблемой. Это случается тогда, когда имеется неясная и неадекватная информация о развитии и тенденциях в организации и еe внешнем окружении.

\section{TИПЫ ПРОБЛЕM}

\section{OPГAНИЗАLИOHНЫE УРОВНИ}

ТИПЫ

РЕШЕНИЙ

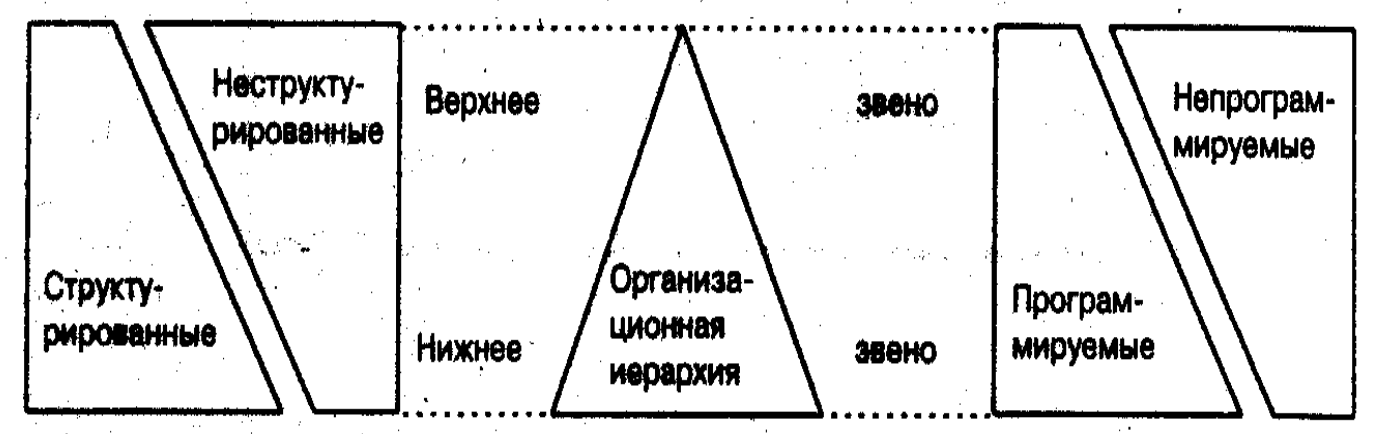

Рис.2. Природа проблем и решений в организации

Признание проблемы является необходимым условием для ее решения, так как если проблема не существует для того, кто принимает решения, то и принятие решения не состоится.

Раз проблема признана, то следующий этап в рассматриваемом процессе - это интерпретация и формулирование проблемы. Интерпретация проблемы — это придание значения той проблеме, которая признана. Проблема может быть определена как возможность, как кризис или как рутинная проблема. Первый тип проблемы необходимо обнаружить и раскрыть. Второй и третий - проявляются сами и требуют вмешательства менеджера.

Рутинные или повторяющиеся проблемы относятся к категории структурированных, а возможности и кризис неструктурированным. Соответственно для каждого типа проблем будут требоваться решения разного типа: для структурированных программированные решения, для неструктурированных - не программированные.

Определение проблемы предполагает получение ответа на следующие вопросы: 1) что действительно происходит в организации? 2) каковы причины происходящего? 3) что за всем этим стоит?

Определение и последующее формулирование проблемы позволяет менеджеру ранжировать ее в ряду других проблем. В основу ранжирования проблемы могут быть положены следующие факторы:

- последствия проблемы (капиталоемкость, эффективность, влияние на... и т.п.);

- воздействие на организацию (что произойдет в результате решения проблемы);

- срочность проблемы и ограничения по времени;

- степень использования способностей и времени руководителя;

- внимание к проблеме (мотивированность и наличие способностей у участников);

- жизненный цикл проблемы (может ли проблема решиться сама собой или в ходе решения других проблем).

Изучение этих факторов позволяет менеджеру определить порядок решения проблем, проранжировав их от наиболее важных до наименее важных. Наиболее важными, как правило, становятся проблемы со следующими характеристиками:

- проблема получает сильную поддержку и давление извне в пользу ее решения (например, вышестоящее руководство настаивает на завершении работы над проектом в течение определенного срока); 


\begin{tabular}{|c|c|c|c|c|c|c|}
\hline \multirow{4}{*}{ Impact Factor: } & ISRA (India) & $=3.117$ & SIS (USA) & $=0.912$ & ICV (Poland) & $=6.630$ \\
\hline & ISI (Dubai, UAE & $=0.829$ & РИНЦ (Russia) & $=0.156$ & PIF (India) & $=1.940$ \\
\hline & GIF (Australia) & $=0.564$ & ESJI (KZ) & $=5.015$ & IBI (India) & $=4.260$ \\
\hline & JIF & $=1.500$ & SJIF (Morocco) & $=5.667$ & OAJI (USA) & $=0.350$ \\
\hline
\end{tabular}

- проблема поддерживается ресурсами, необходимыми для еe решения (например, выделены дополнительные бюджетные средства, материалы, люди);

- решение проблемы открывает возможности, от которых нельзя отказаться (например, выход на рынок с новой продукцией позволяет фирме улучшить конкурентные позиции, получить большую прибыль и увеличить доходы своих работников).

На практике количество проблем, получающих оценку как наиболее важных, обычно превышает возможности менеджера по их решению в рамках имеющегося у него времени.

Поиску альтернатив должен предшествовать этап определения критериев успешного решения. Это помогает избежать многих ошибок, проявляющихся позже.

По мнению многих специалистов, данный этап начинается с определения критериев двух типов: критерий «мы должны» и критерий «мы хотим». Первый тип критерия должен быть определен до того, как будет рассматриваться какая-либо альтернатива.

В случае критерия «мы хотим» рассматриваются те цели, которые желательны, но по отношению к которым необязательно должны разрабатываться какие-либо альтернативы. Критерий «мы хотим» заставляет менеджера думать о всех возможных вариантах, не исключая идеальных. Это способствует развитию творчества путем расширения границ для внесения новых альтернатив. В целом определение данных критериев на ранних этапах процесса принятия решения вынуждает менеджера думать о том, каким будет лучшее решение.

Стадия выработки решения состоит из этапов разработки, оценки и выбора альтернатив. Как только определены факторы, ограничивающие решение, менеджер может начинать работу по поиску альтернатив или возможных направлений действия для решения проблемы. Многие из альтернативных решений легко обнаружить. Они обычно известны из предыдущего опыта, стандартны и легко вписываются в критериальные границы лучшего решения.

Однако нередко возникают новые, уникальные проблемы, решение которых не умещается в привычные и стандартные рамки. В этом случае необходим творческий подход. Существует много методов творческого поиска альтернатив: так, называемая «мозговая атака»; выдвижения предложений; групповой анализ ситуации; причинно-следственная диаграмма; карта мнений. Важно понять, что творческая обстановка при поиске альтернатив создается самим руководителем. Он делает людей творцами нового. Секрет творческой среды - в умелом управлении.

Приводимые ниже шесть шагов могут сделать поиск альтернатив более творческим:

- мотивация на поиск;

- предоставление большего количества информации, позволяющей всесторонне и глубже познать проблему;

- свободное обсуждение и допущение любых идей по решению проблемы;

- создание условий для озарения;

- опробование идеи другими людьми на предмет еe соответствия установленным критериям.

Bce предложенные альтернативы на следующем этапе должны быть сравнены друг с другом или оценены для последующего выбора лучшей из них. Оценка предполагает определение отрицательных и положительных сторон рассматриваемых альтернатив и установление между ними некоего уровня компромисса. Для этого используются как количественные, так и качественные, или неосязаемые, измерители. Последние в основном порождаются отношениями между различными силами, участвующими в решении проблемы (трудовые отношения, политическая ситуация, отношение к риску и т.п.). В практике управления широко используются такие методы, как критериальное уравнение Кепнера-Трегое; платежная матрица; дерево целей, или решений. Наиболее известным из них является метод дерева решений для уравнения и оценки выдвинутых альтернатив. Особенно данный метод полезен в ситуациях, когда менеджер имеет дело с неопределенностью. Метод дает общую картину решения: выборы, риски и исходы, которые могут иметь место. Более того, данный метод помогает открыть новые альтернативы, которые ранее могли быть опущены по каким-то причинам. Метод включает следующие шаги:

- инвентаризация всех альтернатив;

- ранжирование выборов B хронологическом порядке;

- решение о предпочтительности последствий рассматриваемых альтернатив с учетом их капиталоемкости;

- оценка шансов того, что каждое из выделенных событий произойдет.

Выбор альтернативы является своего рода вершиной в процессе принятия решения. Многие не любят этот этап, пытаются избежать его или переложить на другого, так как в ходе данного этапа принимающий решение вынужден брать на 


\begin{tabular}{|c|c|c|c|c|c|c|}
\hline \multirow{4}{*}{ Impact Factor: } & ISRA (India) & $=3.117$ & SIS (USA) & $=0.912$ & ICV (Poland) & $=6.630$ \\
\hline & ISI (Dubai, UAE & $=0.829$ & РИНЦ (Russia) & $=0.156$ & PIF (India) & $=1.940$ \\
\hline & GIF (Australia) & $=0.564$ & ESJI (KZ) & $=\mathbf{5 . 0 1 5}$ & IBI (India) & $=4.260$ \\
\hline & JIF & $=1.500$ & SJIF (Morocco) & $=5.667$ & OAJI (USA) & $=0.350$ \\
\hline
\end{tabular}

себя определенные обязательства по будущему курсу действий. Хороший анализ альтернатив позволяет резко сузить рамки выбора. При выборе альтернативы могут использоваться три подхода: учет прошлого опыта; проведение эксперимента; исследование и анализ. [1]

Привлечение прошлого опыта является, пожалуй, наиболее используемым подходом в выборе альтернативы. Опытные менеджеры не просто используют данный подход, но и испытывают сильную веру в него. Это лежит в основе утверждения о том, что чем выше уровень руководства, тем больше требуется опыта. В определенной степени опыт вырабатывает у руководителя умения и навыки принятия правильных решений.

Опыт в решении проблем и принятии решений развивает умение и навыки в суждении и интуиции. Вместе с тем многие считают, что расчет на прошлый опыт для планирования будущего может быть очень опасным. Это происходит вследствие недостаточного учета и анализа причин прошлых ошибок и неудач. Опыт сам по себе очень ситуационен и может не вписываться в текущую ситуацию. Правильное решение основывается на будущих событиях, а опыт - на прошлых. Опыт становится полезным и мощным инструментом в принятии решений, если имеет место его тщательный анализ, а не слепое следование ему и если в ходе этого анализа выявляются основательные причины успеха или неудач. В этой связи большой интерес для менеджера представляет изучение опыта успешных компаний, равно как и компаний, потерпевших неудачу.

Эксперимент как метод выбора альтернативы основан на том, что берется одна или несколько альтернатив и они апробируются на практике с целью определения того, что же может произойти. Эксперимент широко используется в науке. Существует достаточно веское мнение о необходимости широкого использования данного метода в управлении и, в частности, при принятии решений. Считается, что это чуть ли не единственный путь для менеджера добиться уверенности, что принимаемое решение правильно. Однако следует принять во внимание дороговизну техники экспериментирования. Возможно, это самый дорогостоящий метод. Также сложностью использования эксперимента является и то, что даже после его завершения у менеджера все еще могут оставаться сомнения в правильности выбора, так как возможная будущая ситуация не обязательно будет копировать ситуацию настоящую. Поэтому эксперимент может быть использован только после всестороннего и глубокого рассмотрения и анализа.
Вместе с тем существуют решения, которые просто не могут быть приняты без проведения по ним подтверждающего правильность выбора эксперимента. Так, например, решение о серийном выпуске самолета не может быть принято без производства и испытания одной или нескольких его моделей. Эксперимент также широко используется в маркетинговых решениях. Организационные решения часто проверяются в подразделениях, прежде чем их распространяют на всю компанию. Кадровое решение может быть проверено в ходе ротации или стажировки на новой должности.

Считается, что наиболее общим и, возможно, наиболее эффективным методом отбора альтернатив является проведение исследований и анализа. Этот метод предусматривает решение проблемы на основе поиска взаимосвязей между наиболее важными ее переменными, ограничениями и основами, которые рассматриваются по отношению к поставленным целям. В целом это «кабинетный» подход к принятию решения. Данный метод также предусматривает разложение проблемы на части и изучение каждой из них. Важным инструментом данного метода является разработка и проигрывание с использованием количественных методов и компьютеров различных моделей решения. Разработаны и используются модели с привлечением системного подхода, исследования операций, теории игр, теории очередей, управления запасами, линейного программирования, стоимостного анализа т.п. [2]

Завершающая стадия - это выполнение решения. Она состоит из организации выполнения, решения, анализа и контроля выполнения. Наиболее распространенной ошибкой менеджеров является предположение, что если выбор в отношении решения сделан, то решение обязательно будет выполнено.

Выполнение решения - это устранение проблемы, его породившей, по отношению к которой было принято решение.

Организация выполнения решения предусматривает координацию усилий многих людей. Менеджер должен стремиться избегать потенциальных конфликтов, делать людей заинтересованными и мотивированными на реализацию решения, таким образом расставить людей, чтобы максимально использовать их способности. Для этого, во-первых, необходимо составить план мероприятий, превращающих решение в реальность. Необходимо распределить права и ответственность среди участников. Важно помнить старое правило: «Ничего не происходит, если нет ответственного за действие». Следует также построить коммуникационную сеть для обмена 


\begin{tabular}{|c|c|c|c|c|c|c|}
\hline \multirow{4}{*}{ Impact Factor: } & ISRA (India) & $=3.117$ & SIS (USA) & $=0.912$ & ICV (Poland) & $=6.630$ \\
\hline & ISI (Dubai, UAE & $=0.829$ & РИНЦ (Russia) & $=0.156$ & PIF (India) & $=1.940$ \\
\hline & GIF (Australia) & $=0.564$ & ESJI (KZ) & $=\mathbf{5 . 0 1 5}$ & IBI (India) & $=4.260$ \\
\hline & JIF & $=1.500$ & SJIF (Morocco) & $=5.667$ & OAJI (USA) & $=0.350$ \\
\hline
\end{tabular}

информацией и отрегулировать соответствующие отношения подчинения между участниками. Вовторых, менеджер должен проявить беспокойство о конфликте интересов и принятии данного решения его исполнителями. Этому во многом способствуют различные методы делегирования полномочий и участия в управлении.[3]

Следующий этап - это встраивание в решение механизма получения информации о ходе выполнения решения. Основой такого механизма должна стать система обнаружения ошибок и достижений в действиях по выполнению решения. Когда система такого отслеживания отклонений работает эффективно, тогда проблемы в выполнении решений могут быть предотвращены до того, как они проявятся.

Полученная в ходе отслеживания информация необходима для проведения корректировки действий. Отслеживание и обратная связь занимают в работе менеджера много времени. При этом информация из первоисточника всегда лучше, чем подготовленный кем-то отчет или данные из «вторых» рук. В первом случае замечается больше деталей и нюансов, делается более правильная оценка и достигается более верное восприятие потенциальных проблем и их решений. Также это позволяет показать подчиненным интерес менеджера к выполняемому решению. Принятие решения было рассмотрено выше как рациональный процесс, т.е. как серия стадий и этапов, через которые должен пройти менеджер от начала до конца, чтобы дойти до полного выполнения решения и устранения возникшей проблемы. Соответствует ли это реальной практике? Большинство специалистов, изучавших реальную практику осуществления управленческих решений, ответят «нет», при этом назвав ряд ограничений реального мира, препятствующих применению рациональной модели в процессе принятия решения. Такими препятствиями являются следующие:

- часто менеджеры не знают, что проблема вообще существует, так как они либо перегружены, либо проблема хорошо скрыта от них;

- не представляется возможным по техническим или экономическим причинам собрать всю относящуюся к проблеме информацию;

- ограничения во времени вынуждают менеджеров принимать не лучшие решения;

- во многих случаях рассматриваются не все альтернативы, а при их оценке и выборе мало учитываются так называемые качественные или неосязаемые факторы;

- выполнение решения не всеми менеджерами связывается с самим решением.
Большую роль в принятии решения играет интуиция. Она включает в себя предчувствие, воображение, проницательность. Развитая интуиция - это умение держать все, что связано с проблемой, в голове в течение всего процесса. Всеобщий и одновременный охват проблемы и ее решения позволяет менеджеру с развитой интуицией быстро переходить от этапа к этапу.

\section{Основная часть}

Отечественная легкая промышленность переживает не самые лучшие времена, а потребителю предлагается продукция сомнительного качества, попавшая на наши рынки контрафактным и другими нелегальными путями, то есть не имеющая гарантий для покупателей, чтобы воспользоваться своими правами по защите от недобросовестных производителей и поставщиков [4].

Реанимировать роль и значение стратегии, ориентированной на качество, так как только в этом случае руководители предприятий субъективно и объективно вынуждены будут совершенствовать свои производства, используя нанотехнологии и инновационные процессы, чтобы конкурентоспособные и востребованные материалы и изделия в полной мере удовлетворяли потребности отечественных потребителей. При этом обосновано мнение ученых, что потребление отечественных материалов и изделий регулируется рынком. В этом случае требования рынка должны формировать и производство, подтверждая эту ситуацию, обращают внимание на роль государства и потребителей на формирование устойчивого спроса на отечественные материалы и изделия, а именно: поддерживать ассортимент товаров, регулируя его федеральными, региональными и муниципальными заказами; стимулировать стабильность цен; повышать потребительскую способность и постепенно улучшать их качество. Реализация этих задач создаст основу для того, чтобы потребитель осознал необходимость платить за преимущества качественных материалов и изделий, а производитель осознать, что повышение качества материалов и изделий не может быть связанно только с ростом цен, но и за счет технических инноваций, направленных на применение новых технологических и инженерных решений.

Сегодня, а тем более завтра важна реализация одного из определяющего принципа эффективности производства - производитель изготавливает именно то, что нужно потребителю.

Одной из задач в системе повышения конкурентоспособности региона - выявить потенциал, используемый инновационным центром ЮФО и СКФО. Традиции обувной отрасли в 


\begin{tabular}{|c|c|c|c|c|c|c|}
\hline \multirow{4}{*}{ Impact Factor: } & ISRA (India) & $=3.117$ & SIS (USA) & $=0.912$ & ICV (Poland) & $=6.630$ \\
\hline & ISI (Dubai, UAF & $=0.829$ & РИНЦ (Russia & $=0.156$ & PIF (India) & $=1.940$ \\
\hline & GIF (Australia) & $=0.564$ & ESJI (KZ) & $=\mathbf{5 . 0 1 5}$ & IBI (India) & $=4.260$ \\
\hline & JIF & $=1.500$ & SJIF (Morocco & $=5.667$ & OAJI (USA) & $=0.350$ \\
\hline
\end{tabular}

регионах ЮФО, СКФО и тенденции ее развития дают шанс на успех в случае взаимодействия всех участников процесса - поставщиков, производителей, представителей власти, торговых и сервисных компаний. Первый шаг на пути к такому взаимодействию необходимо сделать в ходе обмена мнений и разъяснения взаимных позиций. Однозначно воспринимают ли участники обувного рынка области те проблемы, которые перед ними стоят? Каков вектор структурных изменений на российском кожевенно-обувном рынке - к развитию или стагнации отрасли? Каковы условия и реальные возможности для развития конкурентоспособного производства в регионе? Какой должны быть поддержка власти на федеральном и региональном уровне? Можно ли в современных условиях делать ставку на взаимодействие и сотрудничество как на реальный фактор конкурентоспособности? Как решить проблему подготовки и закрепления кадров на производстве?

Для обувного бизнеса тема формирования инновационного центра весьма актуальна. Создание инновационного центра - один из самых эффективных инструментов повышения конкурентоспособности территорий. Необходимость формирования инновационных центров в регионах ЮФО и СКФО к управлению конкурентоспособностью предприятий, который состоит в разработке новой промышленной политики стимулирования организации и развития кластеров на основе формирования отношений сетевого сотрудничества и государственно-частного партнерства (кластерной политики) и включает исследование кластеров, кластерную стратегию и методы ее обеспечения являются палочкой выручалочкой на сегодня. С точки зрения процесса управления кластерный подход рассматривается как совокупность этапов и мероприятий по организации кластеров и их развитию, т.е. кластеризации. Такой подход позволит малым и средним предприятиям легкой промышленности успешно конкурировать не только на внутреннем, но и на международном рынке.

Роль региональной и местной власти в запуске и координации инновационных центров очень важна, в связи с этим удалось сформировать эффективный механизм представления интересов бизнеса во взаимоотношениях с властью. Предложен элемент, выполняющий функцию «координатора и коммуникатора». Для развития этого элемента нужен предметный диалог, основанный на взаимном доверии и заинтересованности, прежде всего, между самими субъектами отрасли, - в этом заинтересованы и власть, и бизнес. Необходимо разработать совместные предложения по направлениям, формам и методам государственной поддержки развития инновационных центров, а именно:

осуществление нового строительства, расширения и реконструкции производственных мощностей, объектов жилищного, социальнокультурного назначения, коммунального хозяйства и бытового обслуживания населения, административного управления, министерства чрезвычайных ситуаций, охраны окружающей среды и экологической безопасности на региональном уровне;

содействие в повышении конкурентоспособности продукции промышленных предприятий и ее продвижении на внутреннем и внешнем рынке;

организация и осуществление проектов в области производства программных средств;

обновление материально-технической базы производств кластера, внедрение новых технологий;

сохранение и развитие накопленного потенциала в сфере науки и научного обслуживания; совершенствование механизмов финансирования науки; реализация научных результатов в производственной и социальной сфере региона;

достижение качества образования, соответствующего государственному образовательному стандарту; осуществление регионального заказа на предоставление услуг дополнительного образования; достижение динамичного баланса между рынком труда и подготовкой профессиональных кадров; развитие высшего и среднего профессионального образования.

Предложен комплекс мер по антикризисному управлению легкой промышленностью, включая следующие приоритетные направления:

повымение конкурентоспособности предприятий легкой промышленности;

развитие отраслевых информационных услуг; продолжение модернизации основных фондов;

смягчение недостатка оборотных средств; повышение

эффективности

государственного управления;

расшивка неплатежей.

Сформирован план мероприятий по реализации антикризисной программы в легкой промышленности, включая:

нормативно-правовое и научнометодическое обеспечение антикризисной деятельности;

развитие антикризисной инфраструктуры поддержки предприятий легкой промышленности;

расширение деловых возможностей предприятий легкой промышленности; 


\begin{tabular}{|c|c|c|c|c|c|c|}
\hline \multirow{4}{*}{ Impact Factor: } & ISRA (India) & $=3.117$ & SIS (USA) & $=0.912$ & ICV (Poland) & $=6.630$ \\
\hline & ISI (Dubai, UAE & $=0.829$ & РИНЦ (Russia & $=0.156$ & PIF (India) & $=1.940$ \\
\hline & GIF (Australia) & $=0.564$ & ESJI (KZ) & $=\mathbf{5 . 0 1 5}$ & IBI (India) & $=4.260$ \\
\hline & JIF & $=1.500$ & SJIF (Morocco & $=5.667$ & OAJI (USA) & $=0.350$ \\
\hline
\end{tabular}

финансовые механизмы поддержки и развития антикризисной деятельности предприятий легкой промышленности;

развитие межрегионального

и

международного сотрудничества предприятий легкой промышленности в антикризисной сфере.

Для дальнейшего совершенствования нормативно-правового регулирования антикризисной деятельности представляется целесообразным формирование плана мероприятий по реализации антикризисной программы в легкой промышленности, а именно:

конкретизация и детализация целей устойчивого развития предприятий легкой промышленности должна быть построена в рамках линии развития промышленного сектора экономики, которая базируется на структурных преобразованиях экономики и внедрении антикризисных технологий развития производства и экспорта товаров народного потребления. В рамках развития можно выделить три этапа, сроки которых представлены достаточно условно и могут быть скорректированы в процессе реализации устойчивого развития предприятий легкой промышленности:

2015-2017 гг. - Антикризисное развитие, предусматривающее преодоление кризисных явлений и восстановление кризисных потерь предприятий легкой промышленности, и изыскание ресурсов для последующей модернизационной трансформации легкой промышленности

2018-2022 гг. - Инвестиционное обновление основных средств предприятий легкой промышленности, в том числе качественное повышение конкурентоспособности.

2023-2025гг. - Инновационное развитие начало массового освоения новых видов оборудования и технологий, переход к экспансии на зарубежные рынки товаров легкой промышленности.

Использование разработанных и предлагаемых методических положений по повышению конкурентоспособности региона на основе теории кластера позволит принимать решение о привлечении и рациональном размещении инвестиционных средств, направленных на реализацию необходимых мероприятий по повышению эффективности деятельности субъектов привлекательного кластера и росту их конкурентоспособности.

Для решения поставленной задачи предложен конкурентоспособный ассортимент мужской, женской и детской обуви с учетом факторов, влияющих на потребительский спрос: соответствие основным тенденциям моды с учетом экономических, социальных и климатических особенностей регионов ЮФО и СКФО. В рамках разработанной стратегии будет организовано

производство

конкурентоспособной

продукции

использованием современных механизированных инновационных техпроцессов. Кроме того, будет предусмотрено производство обуви для удовлетворения спроса элитного потребителя с использованием большей доли ручного труда, чтобы придать обуви целевую направленность и высокую востребованность.

Для реализации разработанного ассортимента мужской, женской и детской обуви предложены инновационные технологические процессы её производства с использованием современного технологического оборудования на базе передовых нанотехнологий, формирующие основу для снижения затрат на обувь и, тем самым, повышающие ее конкурентоспособность в сравнении с аналогичным ассортиментом обуви ведущих мировых фирм, с возможностью широко ассортиментного выпуска обуви не только по видам, но и по методам крепления, что придаст ей востребованность и повышенную конкурентоспособность. Предложены компоновки технологического оборудования, которые представляют возможность формировать технологический процесс как для производства мужской, так и детской обуви в объемах, которые определяются имеющимися у регионов производственными площадями и используемыми формами организации производства, но конечно с учетом спроса для обеспечения её реализации в полном объеме.

При этом финансовое благополучие и устойчивость вновь создаваемых предприятий в регионах ЮФО и СКФО во многом зависит от притока денежных средств, обеспечивающих покрытие взятых ими обязательств. Отсутствие минимально-необходимого запаса денежных средств может спровоцировать для предприятий финансовые затруднения. В свою очередь и избыток денежных средств может быть знаком того, что предприятие терпит убытки. Причина этих убытков может быть связана как с инфляцией и обесцениванием денег, так и с упущенной возможностью их выгодного размещения и получения дополнительного дохода. В любом случае именно постоянный анализ денежных потоков позволит предприятию контролировать свое реальное финансовое состояние и предупреждать от банкротства.

Денежные потоки от финансовой деятельности в большой степени формируются при выработке схемы финансирования и в процессе расчета эффективности инвестиционного проекта.

Если изготовленная обувь будет реализована не полностью, предприятие теряет часть прибыли, которая необходима для дальнейшего развития производства. Для снижения убытков 


\begin{tabular}{|c|c|c|c|c|c|c|}
\hline \multirow{4}{*}{ Impact Factor: } & ISRA (India) & $=3.117$ & SIS (USA) & $=0.912$ & ICV (Poland) & $=6.630$ \\
\hline & ISI (Dubai, UAE & $=0.829$ & РИНЦ (Russia) & $=0.156$ & PIF (India) & $=1.940$ \\
\hline & GIF (Australia) & $=0.564$ & ESJI (KZ) & $=\mathbf{5 . 0 1 5}$ & IBI (India) & $=4.260$ \\
\hline & JIF & $=1.500$ & SJIF (Morocco) & $=5.667$ & OAJI (USA) & $=0.350$ \\
\hline
\end{tabular}

производитель должен иметь ежедневные сведения о реализации продукции и принимать эффективные решения, а именно: или своевременно изменять цены на изготавливаемый ассортимент обуви, или же, что более эффективно и оправданно, приступать к производству нового, более востребованного на рынке ассортимента обуви.

Менеджеры по продажам или маркетологи, контролирующие процесс продажи конкретно выпускаемого ассортимента обуви, ежедневно должны рассчитывать поступление денежных средств от своей операционной деятельности. В результате отслеживания за поступлением денежных средств будем иметь информацию об их чистом притоке от своей операционной деятельности. Уменьшение объема продаж приведет к снижению денежного потока и потребует снижение отпускной цены изделия с целью повышения объема продаж. Если такое мероприятие не приводит к увеличению денежного потока, то необходимо принимать своевременное решение о целесообразности дальнейшего выпуска этого ассортимента обуви.

Для данного расчета важным является дифференциация данных, участвующих в расчете. Для расчета себестоимости конкретной выпускаемой модели исходными данными являются постоянные и переменные затраты, которые зависят от производственного оборудования, состава основных и вспомогательных материалов, численности работников и др.

Основными исходными данными, которые используются в процессе мониторинга, являются отпускная цена единицы продукции и объем продаж.

Таким образом, расчет может выполняться ежедневно или в выбираемом временном диапазоне, при этом, задавая только объем продаж и цену единицы изделия за определенный период, будем получать приращение денежного потока за этот период.

Расчеты проводятся на основе оценки степени выполнения и динамики производства и реализации продукции, определении влияния факторов на изменение величины этих показателей, выявлении внутрихозяйственных резервов и разработке мероприятий по их снижению, которые должны быть направлены на ускорение оборачиваемости продукции и уменьшение потерь, что позволит достичь значительного экономического эффекта.

Большое значение в управлении выпуском продукции имеет оценка фактического выпуска и реализации в пределах производственной мощности, то есть в границах «минимальный максимальный» объем производства. Сопоставление с минимальным, безубыточным объемом позволяет определить степень, или зону «безопасности» организации и при отрицательном значении «безопасности» снять с производства отдельные виды продукции, изменить условия производства и тем самым снизить расходы или прекратить производство данной продукции.

Сравнение достигнутого объема выпуска с максимальным объемом, определяемым производственным потенциалом организации, позволяет оценить возможности роста прибыли при увеличении объемов производства, если увеличится спрос или доля объема реализации обуви на рынке.

Для обувного предприятия, стремящегося к прочному положению на рынке, установление цены обуви для реализации имеет ключевое значение для успеха избранной стратегии. Цена является инструментом стимулирования спроса и одновременно представляет собой главный фактор долгосрочной рентабельности его деятельности.

В связи с этим необходимо проводить анализ безубыточности.

Рассмотрены различные соотношения объемов реализации и цен на выпускаемую продукцию. Снижение цен происходит, когда предприятие в целях увеличения объемов продаж использует систему скидок. Данное мероприятие приводит к увеличению выручки от реализации и получению дополнительной прибыли. Однако область дохода не является неограниченной - при достижении некоторого объема производства дальнейшее его расширение становится экономически невыгодным.

Эффективность всех этих мероприятий при создании кластера возможна лишь при активном взаимодействии ветвей власти и обязательно при поддержке на федеральном уровне- ЮФО и СКФО могут полностью или частично разгрузить обувщиков от инфраструктурных затрат при создании новых производств в рамках кластера. А решить вопросы налоговых преференций может только федерация; закрыть границы для серого и чёрного импорта - опять компетенция Москвы, учитывая, что отрасль находится в тяжелом депрессивном состоянии, что для изменений в лучшую сторону нужен очень мощный набор инструментов и властные решения, и совместные действия всех заинтересованных сторон.

Быть может, сейчас, когда донские обувщики видят, насколько быстро их ряды редеют под давлением конкуренции, готовность к совместным действиям будет выше. В противном случае Ростов уже очень скоро перестанет быть обувной столицей юга России. Наконец, институционально-организационный сценарий предполагает ответ на вопрос, как должен быть организован кластер, как он должен 


\begin{tabular}{|c|c|c|c|c|c|c|}
\hline \multirow{4}{*}{ Impact Factor: } & ISRA (India) & $=3.117$ & SIS (USA) & $=0.912$ & ICV (Poland) & $=6.630$ \\
\hline & ISI (Dubai, UAE & $=0.829$ & РИНЦ (Russia & $=0.156$ & PIF (India) & $=1.940$ \\
\hline & GIF (Australia) & $=0.564$ & ESJI (KZ) & $=\mathbf{5 . 0 1 5}$ & IBI (India) & $=4.260$ \\
\hline & JIF & $=1.500$ & SJIF (Morocco & $=5.667$ & OAJI (USA) & $=0.350$ \\
\hline
\end{tabular}

формироваться и выращиваться? Для нас кластер предполагает со организацию как минимум четырёх крупных технологических групп, которые образуют технологическую основу кластера:

прорывные научные лаборатории - опытные производства, на которых создаются основы новых технологий;

разработческие центры, на базе которых будут создаваться макеты и образцы технологий для опробования на экспериментальных производствах;

промышленно-технологические группы, способные осуществлять оснастку производства для изготовления опытных серий;

маркетинговые группы, способные продвигать новый тип продукции на рынок и формировать устойчивых спрос.

Управленческой надстройкой, обеспечивающей взаимосвязь этих четырех крупных технологических групп друг с другом, могут быть:

Совет инвесторов, который принимает решение о приоритетном финансирования того или иного проекта;

экспертный Совет, рассматривающий различные проекты по мере их подготовки к реализации;

креативный изентр, подготавливающий материалы для принятия решений экспертным советом и советом инвесторов.

Достижение цели в области развития кластеров возможно только при проведении комплексной технологической модернизации реального сектора экономики региона. Применительно к ЮФО и СКФО она возможна только при учете интересов всех участвующих хозяйствующих субъектов. Речь идет о таких направлениях, как:

увеличение доли инновационного сектора и внедрение технологических инноваций на предприятиях, образующих кластеры;

развитие предпринимательской деятельности в области крупного, среднего и малого бизнеса и взаимное сотрудничество в целях внедрения инноваций, что ведет к расширению действующих и созданию новых кластеров;

усиление связей и взаимозависимости предприятий промышленности и научноисследовательских и образовательных центров и школ;

совершенствование территориального размещения промышленных предприятий.

В заключение рассмотрения процесса формирования и реализации кластерной политики в регионе укажем, что это - сложная задача, разработка и реализация которой должна носить научный характер. Ее успех зависит от множества факторов и условий, и центральное место здесь принадлежит научным принципам управления и стремлению к динамичному развитию региона, заинтересованности всех ветвей власти, как муниципальных и региональных, так и федеральных ветвей власти.

Тем не менее, наиболее слабым местом предприятий является низкий уровень информационного обеспечения именно технологической подготовки производства. Это объясняется тем, что автоматизированные системы ТПП специализированы и зависят от характера производства, вида выпускаемой продукции, серийности их выпуска. Кроме того, прикладное программное обеспечение АСТПП неоднородно по назначению, оно формируется из набора продуктов, каждый из которых обеспечивает разработку отдельного вида технологических процессов.

Поэтому возникает необходимость в создании информационного обеспечения в виде универсальной базы данных, с целью снижения трудоемкости и повышения эффективности работ на этапе технологической подготовки производства за счет их использования.

Для технологического процесса сборки обуви клеевого метода крепления авторами создано информационное обеспечение, целью которого является формирование паспорта модели и автоматизированный выбор технологического процесса.

Для создания информационного обеспечения авторами выполнены следующие задачи:

выделены критерии, определяющие структуру технологического процесса сборки обуви клеевого метода крепления на основе методов априорного ранжирования и ранговой корреляции;

разработан классификатор и структурная схема кодирования модели обуви для автоматизированного проектирования технологического процесса;

составлена матрица совпадений технологических операций в зависимости от конструкции, материалов и способов обработки заготовок верха, стелечных и подошвенных узлов, каблуков и промежуточных деталей для объективного обоснования порядка составления схемы технологического процесса и алгоритма его выбора;

разработана структурно-логическая модель сборки обуви клеевого метода крепления на основе принципов системного подхода, обеспечивающая выработку оптимальных технологических решений;

разработана информационная поддержка для автоматизированного проектирования технологического процесса сборки обуви в виде 


\begin{tabular}{|c|c|c|c|c|c|c|}
\hline \multirow{4}{*}{ Impact Factor: } & ISRA (India) & $=3.117$ & SIS (USA) & $=0.912$ & ICV (Poland) & $=6.630$ \\
\hline & ISI (Dubai, UAE & $=0.829$ & РИНЦ (Russia) & $=0.156$ & PIF (India) & $=1.940$ \\
\hline & GIF (Australia) & $=0.564$ & ESJI (KZ) & $=\mathbf{5 . 0 1 5}$ & IBI (India) & $=4.260$ \\
\hline & JIF & $=1.500$ & SJIF (Morocco) & $=5.667$ & OAJI (USA) & $=0.350$ \\
\hline
\end{tabular}

совокупности баз данных, которые содержат сведения о различных вариантах выполнения одних и тех же технологических операций в зависимости от оснащенности и мощности предприятия;

построен алгоритм работы программы, в соответствии с которым формируются точные предписания, определяющие вычислительный процесс, ведущий от варьируемых начальных данных к исходному результату;

разработано программное обеспечение, позволяющее формировать технологический процесс сборки обуви клеевого метода крепления с одновременным определением трудоемкости и количества рабочих для производства заданного количества моделей.

Разработанное программное обеспечение соответствует основным показателям качества информационных систем, таких как:

гибкость - способность к адаптации и дальнейшему развитию, возможность приспособления информационной системы к новым условиям, новым потребностям предприятия;

надежность - функционирование без искажения информации, потери данных по «техническим причинам» за счет создания резервных копий хранимой информации, выполнения операций протоколирования, поддержания качества каналов связи и физических носителей информации, использования современных программных и аппаратных средств;

эффективность - возможность решать возложенные на нее задачи в минимальные сроки, обеспечивается оптимизацией данных и методов их обработки, применением оригинальных разработок, идей, методов проектирования и подтверждается его способностью минимально зависеть от ресурсов оборудования: процессорного времени, пространства, занимаемого во внутренней и внешней памяти, пропускной способности, используемой в устройствах связи;

безопасность - свойство системы, в силу которого посторонние лица не имеют доступа к информационным ресурсам организации, обеспечивается настройкой параметров запуска таким образом, что пользователь, запустив приложение, видит только главную кнопочную форму и такое меню и панель инструментов, при котором он не может воспользоваться кнопками, предназначенными для разработчика приложения.

Программное обеспечение в соответствии с алгоритмом обрабатывает выбранные условия и выдает на печать готовый вариант техпроцесса на данную модель обуви с расчетом трудоемкости и количества рабочих, а также паспорт модели. При использовании разработанного информационного обеспечения задача технолога по формированию технологического процесса сводится к выбору конструктивных признаков модели и основных ограничений, к которым относятся производственная мощность, наличие оборудования, производственных площадей; анализу результатов; корректировке выбранных условий (в случае необходимости) и выбору оптимального варианта технологического процесса.

Что касается эффективности внедрения информационного обеспечения, любое предприятие может быть оценено с различных сторон, а именно: экономической, финансовой, организационной, временной, экологической, социальной.

Результат расчетов по любому отдельно примененному методу оценки эффективности предложенного решения способен отразить лишь часть их положительных сторон. Между тем, числовые значения возможных к использованию различных критериев могут значительно различаться, а иногда и находиться в конфликте. В такой ситуации оправдано использование синергетической (комплексной) оценки эффективности решений, которые предполагают определение преимуществ не по одному критерию, а по совокупности критериев.

Эффективность от внедрения представленного информационного обеспечения может быть оценена с двух сторон: социальной и экономической.

Социальный эффект от внедрения информационного обеспечения для автоматизированного проектирования технологического процесса заключается в следующем:

1. В результате внедрения в учебный процесс - повышение уровня подготовки специалистов за счет применения инновационных технологий в образовании.

2. В результате внедрения в производство изменение характера и улучшение условий труда, ресурсная оснащенность трудовой деятельности, повышение профессионализма, увеличение средней продолжительности свободного от «бумажной работы» времени технолога.

Оценка экономической эффективности внедрения информационных технологий зачастую происходит либо на уровне интуиции, либо вообще не производится. С одной стороны, это вызвано нежеланием поставщиков решений тратить значительные усилия на проведение подробного предварительного анализа, с другой стороны, вероятно, присутствует значительная доля недоверия потребителей к получаемым результатам таких исследований. Однако, обе эти проблемы проистекают из одного источника, а именно - отсутствия понятных и надежных 


\begin{tabular}{|c|c|c|c|c|c|c|}
\hline \multirow{4}{*}{ Impact Factor: } & ISRA (India) & $=3.117$ & SIS (USA) & $=0.912$ & ICV (Poland) & $=6.630$ \\
\hline & ISI (Dubai, UAE & $=0.829$ & РИНЦ (Russia & $=0.156$ & PIF (India) & $=1.940$ \\
\hline & GIF (Australia) & $=0.564$ & ESJI (KZ) & $=\mathbf{5 . 0 1 5}$ & IBI (India) & $=4.260$ \\
\hline & JIF & $=1.500$ & SJIF (Morocco & $=5.667$ & OAJI (USA) & $=0.350$ \\
\hline
\end{tabular}

методик оценки экономической эффективности ИТ проектов.

Полная экономическая эффективность использования программного обеспечения для автоматизированного проектирования ТПП состоит из экономии в сфере технологической подготовки производства, которая является следствием повышения производительности труда технологов за счет автоматизированного выбора перечня технологических операций с расчетом трудоемкости и количества рабочих.[5]

В сфере производства экономию получают благодаря выбору оптимального технологического процесса вследствие типизации и унификации принимаемых технологических решений. Кроме того, значительно сокращаются сроки подготовки производства, а этот фактор трудно переоценить в наше время, когда конкурентоспособности можно добиться только при часто изменяющемся ассортименте выпускаемой продукции, а для этого необходимо добиться хороших техникоэкономических показателей работы предприятия.

Эти и другие преимущества автоматизированного выбора технологических процессов, хотя многие из них и сложно определить путем прямых экономических расчетов, способствуют существенному улучшению показателей работы обувных предприятий.

Полученные результаты позволяют говорить о достижении синергетического эффекта как с точки зрения технологии (за счет значительного сокращения времени на технологическую подготовку производства, выбора оптимального технологического процесса, сокращения переналадок технологического процесса при смене ассортимента, выбора правильной последовательности запуска образцов), так и с точки зрения эффективности производства в целом, за счет одновременного достижения социального и экономического эффекта.

Сегодня от предприятия легкой промышленности, стремящегося не просто выжить, но и развиваться, требуется умение не просто грамотно эксплуатировать имеющиеся технологии, но в первую очередь, активно позиционировать себя на рынке, поставляя в короткие сроки качественную, удовлетворяющую требованиям, запросы и ожидания потребителей, продукцию по минимальной цене. Иными словами в настоящее время выживет тот, кто быстрее других выпустит на рынок продукцию, наиболее полно соответствующую требованиям потребителей, обеспечив при этом минимальную себестоимость ее производства.

Что должно предпринять предприятие, чтобы перечисленные показатели стали его конкурентными преимуществами?
1. Понимать не только текущие, но и будущие предпочтения клиентов и уметь разрабатывать виды продукции, соответствующие этим предпочтениям.

2. Обеспечить настройку технологических процессов производства, гарантирующую их минимальную себестоимость за счет идентификации и исключения всех видов издержек, не приносящих ценности продукции.

3. Вывести продукцию на рынок быстрее, чем это сделают конкуренты.

Реализация перечисленных задач будет зависеть от того, насколько отлажено и эффективно будут работать на предприятии все подразделения.

Каким образом можно обеспечить эту отлаженную и эффективную работу? С нашей точки зрения, посредством

посредством определения совокупности процессов или видов деятельности, обеспечивающих производство продукции с характеристиками качества, удовлетворяющими требования, запросы и ожидания потребителей;

установления между процессами четкого и понятного взаимодействия;

определения целей в области качества на уровне предприятия и подразделений, обеспечивающих понимание тех результатов, которые должны быть достигнуты подразделениями, и которые обеспечивают достижение общих целей предприятия;

планирования ресурсов, необходимых для достижения целей;

определения процедур, обеспечивающих выполнение работ в подразделениях наиболее эффективным способом;

измерения результатов и сравнения их с поставленными целями;

анализа и принятия решений о том, что следует улучшить в рамках каждого подразделения.

Таким образом, представлена совокупность процессов, за счет функционирования которых формируется система управления предприятием, ориентирующая его на производство продукции, соответствующей по своим характеристикам требованиям, запросам и ожиданиям потребителей и настраивающая все виды деятельности, связанные с обеспечением производства на показатель эффективности, а именно:

выстраивается система идентификации источников издержек, и разработки адекватных мер по их снижению,

формируются достоверные данные, демонстрирующие эффективность использования вложенных инвестиций, что может способствовать привлечению новых инвесторов; 


\begin{tabular}{|c|c|c|c|c|c|c|}
\hline \multirow{4}{*}{ Impact Factor: } & ISRA (India) & $=3.117$ & SIS (USA) & $=0.912$ & ICV (Poland) & $=6.630$ \\
\hline & ISI (Dubai, UAE & $=0.829$ & РИНЦ (Russia & $=0.156$ & PIF (India) & $=1.940$ \\
\hline & GIF (Australia) & $=0.564$ & ESJI (KZ) & $=\mathbf{5 . 0 1 5}$ & IBI (India) & $=4.260$ \\
\hline & JIF & $=1.500$ & SJIF (Morocco & $=5.667$ & OAJI (USA) & $=0.350$ \\
\hline
\end{tabular}

уменьшается себестоимость продукции, что дает возможность снижать цену, расширять рынок и увеличивать объемы производства;

происходит снижение издержек, обычно связаных с сокращением количества брака и других видов отходов, что положительно сказывается на таких показателях работы предприятия, как влияние на окружающую среду, состояние промышленной безопасности;

формируется имидж социально-

ориентированного предприятия;

выполняется четкая постановка целей и задач перед каждым сотрудником, определяющих результат, который должен быть получен при выполнении работы;

определение ресурсов, необходимых для выполнения работы, и обеспечение ресурсами;

обеспечение знаниями и навыками, необходимыми для понимания того, как следует выполнять работу, чтобы обеспечить ее максимальную эффективность;

измерение результатов работы на уровне сотрудников, подразделений и организации в целом и сравнение результатов с целями;

анализ результатов и адекватное реагирование на них через систему корректирующих и предупреждающих действий.

Как показывает практика, умение реализовать эти процессы на уровне высшего менеджмента создает условия, необходимые для формирования конкурентоспособного предприятия, то есть все это руководитель уже сегодня может взять на вооружение, чтобы обеспечить своим предприятиям эту самую экономическую стабильность.

Кроме того, важно, чтобы наименований продукции было не слишком много. Для большинства российских предприятий основной резерв оптимизации ассортимента до сих пор заложен в значительном сокращении ассортиментного ряда. Слишком большой ассортимент плохо сказывается на экономических показателях - появляется много позиций, которые по объемам продаж не могут выйти даже на уровень безубыточности. В итоге общая рентабельность сильно падает. Только исключение нерентабельных и малорентабельных позиций из ассортимента может дать компании увеличение общей рентабельности на 30-50 \%.

Кроме того, большой ассортимент распыляет силы предприятия, затрудняет грамотное предложение товара клиентам (даже сотрудники отдела продаж не всегда способны объяснить разницу между той или иной позицией или наименованием), рассеивает внимание конечных потребителей.

Здесь будет уместным напомнить о психологии восприятия информации человеком. Реальность такова, что среднестатистический человек способен единовременно воспринять не более 5-7 (реже до 9) смысловых конструктивных решений. Таким образом, человек, делая выбор, сначала выбирает эти самые 5-7 вариантов на основании такого же количества критериев. Если продавец предлагает большее количество критериев выбора, покупатель начинает испытывать дискомфорт и самостоятельно отсеивает незначимые, с его точки зрения, критерии. То же происходит и при выборе собственно товара. Теперь представьте, что происходит, если перед человеком сотня практически не отличимых (для него) товаров, а купить ему нужно один. Люди в такой ситуации ведут себя следующим образом: либо вообще отказываются от покупки, так как не в состоянии сопоставить такое количество вариантов, либо предпочитают то, что уже брали (или что кажется знакомым). Есть и еще одна категории людей (около $7 \%$ ), любители новинок, которые наоборот выберут что-то, что еще опробовано ими. [6]

Таким образом, с точки зрения покупателя (для обеспечения спокойного выбора из поддающихся восприятию вариантов) ассортимент должен состоять не более чем из 5-7 групп по 5-7 наименованиям, т.е. весь ассортимент с точки зрения восприятия оптимально должен состоять из 25-50 наименований. Если наименований объективно больше, то выход состоит только в дополнительной классификации.

Считается общепринятым, что покупателю нужен широкий ассортимент. Этот самый широкий ассортимент часто обозначают даже как конкурентное преимущество. Но на деле получается, что для производителя широкий ассортимент - это сотни наименований продукции, а для потребителя - 7 наименований уже более чем достаточно. Таким образом потребителю нужен вовсе не широкий ассортимент, а необходимое для него разнообразие.

Это возможно, если будут реализованы составные части стратегии развития России до 2020 года, а именно: будет решена задача по переводу экономического развития России от инерционного энергетического сценария к альтернативному инновационному социально ориентированному типу развития, при формировании эффективной промышленной политики, для чего необходимо:

- разработать и законодательно закрепить основы эффективной государственной промышленной политики как системы согласованных целей, приоритетов и действий государственных органов, бизнеса и науки по повышению эффективности работы промышленности, обеспечению высокой 


\begin{tabular}{|c|c|c|c|c|c|c|}
\hline \multirow{4}{*}{ Impact Factor: } & ISRA (India) & $=3.117$ & SIS (USA) & $=0.912$ & ICV (Poland) & $=6.630$ \\
\hline & ISI (Dubai, UAE & $=0.829$ & РИНЦ (Russia) & $=0.156$ & PIF (India) & $=1.940$ \\
\hline & GIF (Australia) & $=0.564$ & ESJI (KZ) & $=\mathbf{5 . 0 1 5}$ & IBI (India) & $=4.260$ \\
\hline & JIF & $=1.500$ & SJIF (Morocco) & $=5.667$ & OAJI (USA) & $=0.350$ \\
\hline
\end{tabular}

конкурентоспособности продукции, товаров и услуг и неуклонного роста производства. При её формировании предусмотреть опережающий рост во всех отраслях высокотехнологичной продукции с увеличением её доли в общем объеме промышленного производства к 2020 году не менее $50 \%$, равенство субъектов промышленной политики, гарантии прав собственности;

- обеспечить реализацию особых мер поддержки приоритетных высокотехнологичных отраслей, чтобы создать условия для эффективного развития всей промышленности России;

Обеспечить увеличение объема инвестиций, создание экономических и правовых предпосылок для внедрения и использования высоких технологий и новых материалов, в первую очередь разрабатываемых в России, для этого следует:

- законодательно закрепить основы национальной инновационной системы в Российской Федерации; установить повышающий коэффициент на расходы на НИОКР, включаемые в себестоимость; снизить НДС до $12 \%$; освободить от налогообложения прибыль предприятий, инвестируемую в производство; создать институты долгосрочного кредитования модернизации и технического перевооружения промышленности под невысокий процент; усовершенствовать систему администрирования НДС, изменить порядок и сроки уплаты налогов для пополнения предприятиями промышленности собственных оборотных средств; осуществить переход на дифференцированную ставку налога на добычу полезных ископаемых в зависимости от природных условий, степени выработанности месторождений и т.д.;

- разработать и осуществить меры по борьбе с ценовым монополизмом, по стабилизации тарифов на услуги естественных монополий, подготовить и принять федеральный закон «О ценовой и тарифной политике»; содействовать созданию и продвижению отечественных национальных, региональных и корпоративных брендов отечественной продукции для развития конкурентоспособной среды с целью создания конкурентной продукции, для чего внедрить систему качества, содействовать реализации программ, направленных на выявление, независимую оценку качества и продвижение отечественной продукции, активизировать работы по стандартизации, включая затраты на научные исследования в этой сфере по разработке новых и корректировке существующих национальных стандартов;

- учитывать, что машиностроение является системообразующим комплексом, для чего обеспечить в сжатые сроки его модернизацию и восстановление технологической основы национального

машиностроительного комплекса - станкостроения. В этих целях использовать как отечественные разработки, так и закупку зарубежной техники и технологий, используя международное разделение труда, шире задействовать механизм лизинга. Кроме общих мер поддержки промышленности, необходимо дополнительно подготовить и принять государственную стратегию развития станкоинструментальной промышленности на период до 2025 года, включая реализацию специальных целевых программ, направленных на финансирование перспективных научных разработок;

- модифицировать размеры и порядок взимания таможенных сборов для стимулирования импорта новейшего технологического оборудования при одновременном содействии возрождению отечественного производства такого оборудования, в частности, отменить таможенные пошлины и НДС на ввоз нового импортного технологического оборудования, не производимого в стране;

- разработать и принять комплекс специальных мер по обеспечению машиностроения и станкостроения научными и инженерными кадрами, высококвалифицированными рабочими, особенно в сфере научных исследований и прикладных разработок, сформировать систему трудоустройства молодых специалистов; разработать и принять поправки в Налоговый кодекс (гл. 25), устанавливающие режимы ускоренной амортизации и преференций (премий), позволяющих амортизировать активную часть основных фондов в объеме, превышающем их балансовую стоимость;

- принять меры по стимулированию системы государственного и коммерческого лизинга технологического оборудования в целях технического перевооружения отраслей машиностроения; рассмотреть возможность предварительной 100-процентной оплаты из средств федерального бюджета стоимости поставок предприятиям уникального импортного оборудования, в т. числе на лизинговой основе, необходимого для целей технического перевооружения машиностроения и станкостроения;

- ввести в практику проведение систематической всероссийской переписи металлообрабатывающего оборудования, что позволит иметь объективные данные о состоянии станочного парка машиностроительных предприятий;

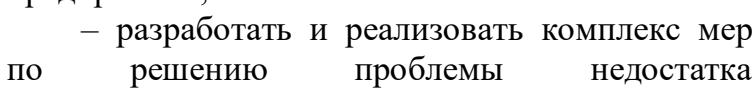
квалифицированных кадров в промышленности, по повышению качества подготовки кадров в 


\begin{tabular}{|c|c|c|c|c|c|c|}
\hline \multirow{4}{*}{ Impact Factor: } & ISRA (India) & $=3.117$ & SIS (USA) & $=0.912$ & ICV (Poland) & $=6.630$ \\
\hline & ISI (Dubai, UAE & $=0.829$ & РИНЦ (Russia) & $=0.156$ & PIF (India) & $=1.940$ \\
\hline & GIF (Australia) & $=0.564$ & ESJI (KZ) & $=\mathbf{5 . 0 1 5}$ & IBI (India) & $=4.260$ \\
\hline & JIF & $=1.500$ & SJIF (Morocco) & $=5.667$ & OAJI (USA) & $=0.350$ \\
\hline
\end{tabular}

высших учебных заведениях, по обеспечению молодых специалистов жильем на льготных условиях, ввести в практику подготовку специалистов по государственному заказу, на основе частно-государственного партнёрства обеспечить современной техникой и общежитиями профессионально-технические училища, разрешить предприятиям средства, израсходованные на подготовку кадров относить на затраты производства в полном объёме, принять специальные законодательные и нормативные документы, направленные на обеспечение промышленное освоение Сибири и Дальнего Востока;

- - разработать и законодательно закрепить комплекс мер, обеспечивающий заинтересованность хозяйствующих субъектов в активном участии в проектах повышения ресурсо- и энергоэффективности, включая элементы денежно-кредитной политики, валютного и инвестиционного регулирования, механизмы субсидирования, специальные налоговые и амортизационные режимы;

- - реализовать комплекс мер, направленных на массовое развитие малых и средних предприятий в промышленнопроизводственной, инновационной сферах и в сфере услуг, в первую очередь, в части обеспечения малым и средним предприятиям доступа к производственным помещениям, закупки оборудования, в т. числе на лизинговой основе, развития микрофинансирования и кредитной кооперации;

- - принять меры для создания российской перерабатывающей промышленности равных конкурентных условий с импортерами, ускорить разработку и принятие федерального закона «О торговле» и сопутствующих нормативных актов по организации эффективного функционирования российской оптовой и розничной торговли;

- - разработать стратегию регионального промышленного развития субъектов РФ, в том числе территориального размещения производительных сил на долгосрочную перспективу, увязать развитие региональной инфраструктуры с размещением промышленных объектов;

- - четко прописать систему реализации основополагающих целей государственной промышленной политики, обеспечивающих решение системных проблем реального сектора экономики, соотнести потребность в инвестициях, источники инвестиций и реально достижимые социально-экономические результаты.[7-8]

В Стратегии развития легкой промышленности на период до 2025 года и плана мероприятий по еe реализации учтены национальные интересы России (повышение уровня и качества жизни населения, здоровья нации, стратегической и экономической безопасности государства), предложения субъектов Российской Федерации, общественных организаций и объединений о необходимых мерах поддержки отрасли по приоритетным направлениям ее развития.

В основу Стратегии был заложен переход легкой промышленности на инновационную модель развития. Особое внимание уделено вопросам защиты внутреннего рынка от теневого товарооборота, технического перевооружения и модернизации производства, импортозамещения и экспорта.

Сегодня легкая промышленность Российской Федерации - это важнейший многопрофильный и инновационнопривлекательный сектор экономики.

Вклад легкой промышленности в промышленное производство России сегодня составляет порядка 1 \% (в 1991 г. этот показатель был равен $11,9 \%$ и соответствовал уровню развитых стран, таких как США Германия и Италия, которые на протяжении всех этих лет сохраняют этот показатель на уровне 8-12\%), в объеме экспорта $-1,3 \%$.

В настоящее время в легкой промышленности функционирует 14 тыс. крупных, средних и малых предприятий, расположенных в 72 регионах страны. Около 70 \% предприятий являются градообразующими. Среднесписочная численность промышленнопроизводственного персонала, занятого в отрасли, 462,8 тыс. человек, $75 \%$ которого составляют женщины. Научное обеспечение отрасли осуществляют 15 учебных, научно исследовательских и проектных институтов, многие разработки которых соответствуют и даже превышают мировой уровень.

Основными территориями размещения предприятий, определяющих промышленную и экономическую политику отрасли, являются Центральный (55 предприятий), Приволжский (30) и Южный (17) федеральные округа, которые имеют наибольший удельный вес в общем объеме производимой продукции и являются наиболее социально значимыми.

Результаты работы отрасли за 2014 г. показали, что она в условиях кризиса в состоянии нарастить объемы производства в подотраслях, ориентированных непосредственно на рынок. Следует отметить, что в условиях кризиса резко сужается ассортимент поставляемых в Россию товаров. Это дает отечественной легкой промышленности стратегические возможности для занятия освобождающихся ниш и упрочения своих позиций на рынке. 


\begin{tabular}{|c|c|c|c|c|c|c|}
\hline \multirow{4}{*}{ Impact Factor: } & ISRA (India) & $=3.117$ & SIS (USA) & $=0.912$ & ICV (Poland) & $=6.630$ \\
\hline & ISI (Dubai, UAE & $=0.829$ & РИНЦ (Russia & $=0.156$ & PIF (India) & $=1.940$ \\
\hline & GIF (Australia) & $=0.564$ & ESJI (KZ) & $=\mathbf{5 . 0 1 5}$ & IBI (India) & $=4.260$ \\
\hline & JIF & $=1.500$ & SJIF (Morocco & $=5.667$ & OAJI (USA) & $=0.350$ \\
\hline
\end{tabular}

В 2014 г. оборот розничной торговли продукцией легкой промышленности составил 2,0 трлн руб., его доля в розничном товарообороте страны $14,5 \%$, а в розничном товарообороте непродовольственных товаров 26,3\%. По уровню потребления продукция легкой промышленности уступает только продовольственным товарам, намного опережая рынки бытовой электроники, легковых автомобилей и других товаров. С учетом макроэкономических показателей и тенденций развития рынок товаров легкой промышленности к 2020 г. может составить свыше 3,3 трлн руб.

Существующие преференции и решаемые в той или иной степени проблемы на федеральном и региональном уровнях пока недостаточны, чтобы устранить влияние негативных факторов на развитие отрасли и превратить ее в конкурентоспособный и саморазвивающийся сектор экономики, а отечественным производителям укрепить свои позиции на внутреннем рынке и на равных конкурировать на мировом рынке не только с производителями Китая, Турции, Индии и ряда других развивающихся стран, но и со странами ЕС и США.

Ситуацию в отрасли еще более усугубил мировой финансовый кризис. В условиях кризиса даже те предприятия, которые за последние годы добились положительных результатов в инновационном развитии, уделяя значительное внимание модернизации производства, уже вынуждены и будут вынуждены в ближайшие годы сокращать объемы производства и отказываться от долгосрочных вложений. Это обусловлено возникшими трудностями, связанными с привлечением банковских кредитов (доля заемных средств в оборотных средствах за последние годы достигла 40 \%), с одной стороны, увеличением объемов официального импорта, контрафактной и контрабандной продукции, падением спроса и замедлением реализации многих видов товаров потребительского и производственно-технического назначения, сокращением рабочих и специалистов - с другой стороны.

Отсутствие кардинальных мер по решению выявленных проблем существенно скажется на экономике отрасли, еe технологическое отставание в обозримой перспективе может стать необратимым процессом, что приведет к деградации наукоемких производств, к усилению товарной зависимости от зарубежных стран, потери государства будут геометрически расти, что повысит стратегическую и национальную опасность России.

Изменить сложившуюся ситуацию можно, только разработав и реализовав антикризисные меры и мероприятия, направленные на подъем экономики легкой промышленности, придание ей новых импульсов в инновационном, социальном и региональном развитии, в повышении конкурентоспособности и эффективности производства на новом технико-технологическом уровне. Сегодня отрасль обеспечивает своей продукцией только четверть платежеспособного спроса населения, а мобилизационные потребности страны - всего лишь на 17-36\%, что противоречит закону о безопасности государства, согласно которому в объеме продукции стратегического назначения доля отечественной должна составлять не менее $51 \%$. Поэтому сегодня перед легкой промышленностью стоят новые вызовы и задачи, решение которых требует новых подходов не только на краткосрочную, но и на долгосрочную перспективу.

Это обусловило цель Стратегии создание условий для ускоренного инновационного развития легкой промышленности России, обеспечения эффективного соответствия объемов производства, качества и ассортимента продукции совокупному спросу потребителей, повышения национальной значимости отрасли и ее имиджа в мировом сообществе.

Цели и задачи Стратегии соответствуют проводимой политике государства в области инновационного и социально-экономического развития России в среднесрочной и долгосрочной перспективе. Стратегия призвана стать: одним из основных инструментов в решении проблем отрасли и взаимоувязать задачу ее экономического роста с обеспечением потребностей граждан страны, силовых структур и смежных отраслей в качественных и доступных потребительских товарах, в продукции технического и стратегического назначения.

Реализация Стратегии даст возможность легкой промышленности России стать индустриально развитой отраслью, которая будет обеспечивать работой многие тысячи людей, повышать благосостояние работающих, укреплять стратегическую и экономическую безопасность страны.

Главный результат Стратегии - это переход легкой промышленности на качественно новую модель инновационного, экономического и социального развития, основа которой - новая технологическая и научная база, новые методы управления производством, взаимосвязь науки, производства и бизнеса. Это обеспечение эффективного соответствия объемов производства, качества и ассортимента продукции совокупному спросу российского и мирового рынков.

Не менее важно понимать роль и значение качественной деятельности, то есть насколько 


\begin{tabular}{|c|c|c|c|c|c|c|}
\hline \multirow{4}{*}{ Impact Factor: } & ISRA (India) & $=3.117$ & SIS (USA) & $=0.912$ & ICV (Poland) & $=6.630$ \\
\hline & ISI (Dubai, UAE & $=0.829$ & РИНЦ (Russia) & $=0.156$ & PIF (India) & $=1.940$ \\
\hline & GIF (Australia) & $=0.564$ & ESJI (KZ) & $=\mathbf{5 . 0 1 5}$ & IBI (India) & $=4.260$ \\
\hline & JIF & $=1.500$ & SJIF (Morocco) & $=5.667$ & OAJI (USA) & $=0.350$ \\
\hline
\end{tabular}

руководители прониклись в сущность вещей, научились управлять вещами, изменять их свойства (ассортимент), форму, заставляя служить человеку без существенного ущерба природе, на благо и во имя человека.

О необходимости проведения грамотной промышленной политики в последнее время начали говорить и политические лидеры, и в правительстве. Однако если внимательно рассмотреть нормативные, методические документы по структурной перестройке промышленности, то появляется мысль, не наступаем ли мы здесь на те же грабли, на которые наступали все годы реформ [8].

Специалист в области качества с мировым именем Э.Деминг, который в свое время был научным консультантом правительства Японии и выводил Японию из экономического кризиса, в своей книге «Выход из кризиса» говорит: «... управление бумажными деньгами, а не долговременной стратегией производства - путь в бездну».

По поводу нужно ли государству проводить промышленную политику, можно привести высказывание выдающегося экономиста прошлого Адама Смита, который 200 лет назад заложил основы научного анализа рыночной экономики. О роли государства он говорил: «... только оно может в интересах нации ограничивать алчность монополистов, авантюризм банкиров и эгоизм торговцев».

Каковы сегодня результаты экономической деятельности, каковы достижения в этой сфере? Рост золотовалютных запасов, снижение инфляции, профицит бюджета и другие финансово-экономические достижения. А что, разве это является конечным результатом государственного управления? А не количество и качество товаров и услуг, реализуемых на внутреннем и внешнем рынках и неплатежеспособность населения приобретать эти товары и услуги? И, в конечном счете, на качество жизни населения страны?

Поэтому вполне закономерно сегодня ставится задача для всех уровней исполнительной и законодательной властей - повышение качества жизни граждан России.

Проведем укрупнено факторный анализ проблемы «качество жизни». Качество жизни граждан зависит от качества потребляемых товаров и услуг в полном диапазоне - от рождения до ритуальных услуг, а также от платежеспособности граждан, которая позволяет приобретать качественные товары и услуги. Названные два фактора (качество и платежеспособность) зависят от состояния экономики страны, которая в свою очередь зависит от эффективности работы предприятий различных отраслей экономики, в том числе и легкой промышленности. Эффективность же работы предприятий зависит от состояния менеджмента, от уровня применения современных методов маркетинговых решений.

Проблемы повышения качества,
конкурентоспособности материалов и изделий на современном этапе развития российской экономики приобретают все большее значение. Как показывает опыт передовых стран, которые в свое время выходили из подобных кризисов (США в 30-х годах, Япония, Германия - в послевоенный период, позднее - Южная Корея и некоторые другие страны), во всех случаях в основу проведения промышленной политики и подъема экономики была положена стратегия по повышению качества, конкурентоспособности продукции, которая была бы способна завоевать как внутренний, так и внешние рынки сбыта. Все же остальные составляющие реформы экономические, финансово-кредитные, административные - были подчинены этой основной цели [9].

Положительные изменения качества товаров предполагают качественные сдвиги в технике, технологии, организации и управлении производством. Производство должно совершенствоваться, что не означает становиться более затратным.

Авторы абсолютно верно обратили внимание на одно, обычно ускользающее в проблемной суете, явление - историчность экономики. Такой, какой мы ее воспринимаем сейчас, экономика была не всегда и навсегда такой не останется. Экономическая жизнь изменяется во времени, что заставляет нас настраиваться не ее изменяющееся бытие. Современная экономика построена на рыночном фундаменте и законы рынка диктуют ей свои правила. На первом плане прибыль, конкуренция, эффективность, единоначалие. Долго ли так будет продолжаться? Аналитики утверждают, что уже нарастают симптомы нового экономического порядка. Очередной виток экономической спирали также закрутится вокруг рыночного стержня, но значение рынка не останется тотальным. Приоритет рыночной конкуренции, агрессивно вытесняющей на обочину «социалку», не совместим с перспективой экономического развития, подтверждением чего служит устойчивое стремление социал-демократии на Западе развернуть экономику фронтом на социальное обеспечение, справедливое распределение прибыли. Новую экономику именуют временно «рачительной». Она требует гуманизации не только в распределении национального богатства. Гуманизируется и само производство, включая систему управления. Нынешний принцип: «выживает сильнейший, наиболее приспособленный», сменит «социально- 


\begin{tabular}{|c|c|c|c|c|c|c|}
\hline \multirow{4}{*}{ Impact Factor: } & ISRA (India) & $=3.117$ & SIS (USA) & $=0.912$ & ICV (Poland) & $=6.630$ \\
\hline & ISI (Dubai, UAE & $=0.829$ & РИНЦ (Russia) & $=0.156$ & PIF (India) & $=1.940$ \\
\hline & GIF (Australia) & $=0.564$ & ESJI (KZ) & $=\mathbf{5 . 0 1 5}$ & IBI (India) & $=4.260$ \\
\hline & JIF & $=1.500$ & SJIF (Morocco) & $=5.667$ & OAJI (USA) & $=0.350$ \\
\hline
\end{tabular}

производственное партнерство - управляющий и изготовитель сделаются членами одной команды. Массовое производство уступит место организации, соответствующей реализации принципа - «производитель изготавливает именно то, что нужно потребителю». «Рачительная» экономика будет ориентирована на ресурсосберегающие технологии и экологичность производства. Она потребует нового взгляда на коренные понятия.

И потому изменится и философия качества. Надо быть готовым к грядущим событиям.

Качеству «на роду написано» быть во все времена в эпицентре и научных, и дилетантских размышлений. Проблема обеспечения качества деятельности не просто универсально актуальная, она - стратегическая. Дилемма в отношении к качеству разумна лишь в пределах противопоставления соотношения действий «непосредственных» и «опосредованных». Высказывания «это все о нем», обязано происхождением качеству. «Забыть» о проблеме качества можно исключительно потому, что всякая плодоносная и светоносная деятельность направлена в конечном счете на совершенствовании качества. Качество или «на уме», или «подразумевается». Из соотношения в динамике этих проекций проблемы качества в творческом мышлении выстраивается соответствующий график, отражающий актуальность и рентабельность деятельности, направленной на развитие производства [10].

И вполне понятно акцентируется значимость этих особенностей для обеспечения потребителей востребованной продукции, в подтверждении этого был проведён укрупнено факторный анализ проблемы «качество жизни». Качество жизни граждан зависит от качества потребляемых товаров и услуг в полном диапазоне - от рождения до ритуальных услуг, а также от платежеспособности граждан, которая позволяет приобретать качественные товары и услуги. Названные два фактора (качество и платежеспособность) зависят от состояния экономики страны, которая в свою очередь зависит от эффективности работы предприятий различных отраслей экономики, в том числе и легкой промышленности. Эффективность же работы предприятий зависит от состояния менеджмента, от уровня применения современных методов менеджмента.

Сегодня наиболее существенное влияние имеют международные стандарты по менеджменту качества. Применение в них современных методов позволяет решать не только проблему повышения качества, но и проблему экономичности, и проблему производительности. То есть сегодня понятие «менеджмент качества» переходит в понятие «качество менеджмента».

Таким образом, решение задачи повышения эффективности и конкурентости экономики, а в конечном счете и качества жизни, невозможно без осуществления продуманной и грамотной промышленной политики, в которой инновации и качество должно стать приоритетной задачей.

Результаты исследований, проведенные по программе развития в ООН, позволили измерить долю «человеческого фактора» в национальном и общемировом богатстве: $65 \%$ богатства мирового сообщества составляет вклад человеческого потенциала и только треть мирового богатства приходится на природные ресурсы и производственную структуру. Стратегия, ориентированная на качество, несомненно, способствует возрастанию и самой роли субъективного фактора в развитии производства, и более полному всестороннему удовлетворению самих человеческих потребностей. Стремление «жить по разумным потребностям», так же, как и необходимость «работать по возможностям», вместе с коммунистическим идеалом никто отменить открыто и официально не рискнул, понимая абсурдность отрицания сущностных сил человека. В «горячем» состоянии проблему качества устойчиво поддерживают и внутренние силы активного сознания и внешние жизненные факторы. Высшая функция сознания познавательная, поэтому вполне оправдано мнение, что познавая природу, мы открываем ее качества, состояние качества, уровни качества, воплощая новые знания в производство. Пост классическая экономическая мысль сместила качество в сторону потребления, пытаясь придать производству «человеческое лицо» человек отчуждает себя в процессе производства, но мера эта вынужденная и в системном понимании - временная, условная. Труд - своего рода «страшные котлы», которые нужно было преодолеть Ване-дурачку, чтобы превратиться в Ивана-царевича.

И здесь абсолютно верно, что главное в производстве - результат, а не процесс. Потребление регулирует рынок. Следовательно, требования рынка должны доминировать в производстве. Задача общества - всемирно способствовать развитию спроса на рынке: поддерживать ассортимент товаров, стимулировать стабильность цен, повышать покупательную способность, улучшать качество товаров. Э. Деминг, называя «сеть смертельных болезней» современного производства, на первое место ставит «планирование производства, не ориентированное на такие товары и услуги, на которые проявляет спрос рынок». Попробуйте ему возразить. Производство при переходе от индустриального к постиндустриальному 


\begin{tabular}{|c|c|c|c|c|c|c|}
\hline \multirow{4}{*}{ Impact Factor: } & ISRA (India) & $=3.117$ & SIS (USA) & $=0.912$ & ICV (Poland) & $=6.630$ \\
\hline & ISI (Dubai, UAE & $=0.829$ & РИНЦ (Russia) & $=0.156$ & PIF (India) & $=1.940$ \\
\hline & GIF (Australia) & $=0.564$ & ESJI (KZ) & $=5.015$ & IBI (India) & $=4.260$ \\
\hline & JIF & $=1.500$ & SJIF (Morocco) & $=5.667$ & OAJI (USA) & $=0.350$ \\
\hline
\end{tabular}

обществу массового потребления мыслится в качестве функции рынка, наполняя эти свойства качества критериями, а именно[11]:

- - идеология качества - перспектива развития производства;

- - управление качеством - это комплексный подход к решению проблемы качества;

- - мода и техническое регулирование составляющие качества изготавливаемой обуви;

- - системы качества «УПОРЯДОЧИВАНИЕ/5 S» и «ТРИ «НЕ» - не только основа стабильности и безопасности производства, но и гарантия качества;

- - качество на рынке - это парадигма формирования производства удовлетворяющего потребности рынка;

- - реклама всегда на службе качества;

- - экскурс в прошлое как гарантия качества в будущем;

- - модель оценки качества продукции это приоритеты производстве;

- - прогнозирование затрат на качество при разработке нового ассортимента обуви - залог ее востребованности и ее конкурентоспособности;

- методика деловой визуальной оценки изделия - средство оценки эффективности качества;

- повышение

качества и конкурентоспособности отечественной спецобуви;

- - о показателях оценки качества обуви как инструмент для формирования востребованной продукции;

- - качество и рынок: брак по расчёту и это бесспорно;

- - стабильность работы предприятий гарант качества выпускаемой ими обуви - все эти аспекты вместе и обеспечивают революцию качества, гарантирующие производителю стабильный успех на рынке с не стабильным спросом.

В заключение ещё раз хотелось бы заострить внимание, что всё это станет реальностью, если будет реализовано одно условие, а именно, продукция легкой промышленности будет производиться высокого качества и с учетом интересов этого самого потребителя.[12]

В истории проблемы качества выделяются два периода. В течение первого серьезный интерес к тому, что есть качество, был ограничен в основном профессиональной теорией. Качество и его системное положение пытались определить философы, однако, и в многочисленных философских спорах понятие «качество» не принадлежало к числу главных проблем.

Актуализация теории качества оказалась в зависимости от степени разработанности системообразующего философского понятия «бытие» в контексте базовых производных от него понятий, т.е. тех понятий, которые помогают осуществить восхождение от предельно абстрактного утверждения существования с единственным отличающим свойством быть, существовать, к конкретному пониманию с устоявшемся содержанием, благодаря ответам на производные вопросы, такие, как «Из чего есть все?», «За счет чего все существует?», «Есть ли небытие?», «В каких системных формах бытие обретает свою определенность?».

По-видимому, именно последний из перечисленных вопросов вывел философию на «тропу» того толкования качества, которое «зацепило» не только тех, кто «обустраивал» принципиально новый в человеческой истории тип мировоззрения.

Логично предположить, что проблема субстанции бытия, как первый шаг к теории качества, вряд ли кого волновал за пределами ограниченного сообщества философов. Все свидетельствует о том, что интересно это было тем, чей взор был обращен в Космос, в глубины его конструкции, а подавляющее большинство земляков философов находилось во власти земных проблем.

Для масс разнообразие и возможность выбора благ по существу были не доступны. Плебеи требовали: «Хлеба и зрелищ!». Праздником жизни во всем разнообразии ее проявления наслаждалась немногочисленная аристократия. Проблема качества жизни решалась в соответствии с социокультурной архитектурой общества. Проблема эта бесспорно имела место, но вызреть в актуальную для общества не могла. Причина проста - отсутствие достаточного уровня массовой востребованности качественного продукта.

Проблема качества обрела масштабы социальной актуальности в условиях перехода к экономике массового производства, демократизации общественных отношений, развития просвещения, доступности образования и других культурных ценностей. Чтобы вопрос о качестве сделался одним из наиболее важных для общества, нужно было, чтобы он стал актуальным для большинства тех, кто образует это общество. Без права на свободу и покупательской способности делать выбор, «качество»не способно быть среди приоритетов массового сознания. Элитные же запросы на качество разрабатываются в эксклюзивных, нетрадиционных теориях, главная цель которых не достижение истины, а удовлетворение потребности заказчиков.

Разумеетя, о качественных и количественных характеристиках явлений естественного и искусственного происхождения 


\begin{tabular}{|c|c|c|c|c|c|c|}
\hline \multirow{4}{*}{ Impact Factor: } & ISRA (India) & $=3.117$ & SIS (USA) & $=0.912$ & ICV (Poland) & $=6.630$ \\
\hline & ISI (Dubai, UAE & $=0.829$ & РИНЦ (Russia) & $=0.156$ & PIF (India) & $=1.940$ \\
\hline & GIF (Australia) & $=0.564$ & ESJI (KZ) & $=\mathbf{5 . 0 1 5}$ & IBI (India) & $=4.260$ \\
\hline & JIF & $=1.500$ & SJIF (Morocco) & $=5.667$ & OAJI (USA) & $=0.350$ \\
\hline
\end{tabular}

знали задолго до того, когда эти признаки актуализировались в общественном бытии и отражающим его развитие сознании, но, в свете нашего исследования, существование знания качества де факто не столь значимо. Предмет исследования не осознание качества, а развитие понимания качества на разных горизонтах общественной истории.

Развитие - универсальное состояние всего существующего от простейших материальных субстратов до высших форм мышления. Совершенствовались и качество, и количественное его выражение, прояснялась зависимость качественно-количественных изменений. Смещались акценты внимания с количества на качество. Доказав свою эволюционную прочность, человечество переключалось на принцип: «брать не числом, а умением». На смену борьбы за выживание пришло стремление к качественному уровню жизни в широком диапазоне толкования. Началась борьба за достойную качественную жизнь.

Как показывает история, уйдя от дикости и варварства, заложив основы цивилизации, люди заметно изменились во внешних формах своего проявления, но в недра человеческой натуры цивилизация проникает медленно и тяжело. Биологическая история заложила в природу человека активное начало, совмещенное с развитой способностью мышления, заметно превосходящей все иные виды отражения. Но вся эта надстройка сформировалась над достаточно жестким животным каркасом, подчиненным системной цели выжить в борьбе. Условия борьбы трансформировались, внося коррективы в средства и формы, однако сама природная база оказалась весьма инерционной. [13]

Переход от естественного эгоизма биологического уровня к разумно-деятельному эгоизму, несмотря на известные цивилизационные средства культивации, не отвечал прогнозам ни романтиков, ни реалистовоптимистов. Цивилизация отметилась не цивилизационными формами отношений в движении к качественной жизни, чем еще больше актуализировала интерес к качеству. Чтобы стать в ряд с самыми важными проблемами, качество должно было предстать в нескольких функциях: как цель, как средство, как условие развития всех социальных субъектов на всех уровнях жизнедеятельности.

История для историков - события и участники, выстроенные во временной последовательности, своего рода хронология значимых фактов общественной и, отчасти, личностной жизни. Философ и специалистнеисторик видят в истории свои интересы. Философский и специальный интерес к истории продиктован потребностью понять диалектику процесса применительно к деятельности человека. Специалист стремиться обнаружить в прошлом тенденции пути решения своей проблемы, подчас далеко не частной.

Интуитивно еще на заре цивилизации термин история (historia) трактовался в смысле исследования искомого процесса в противоположность хронологическому описанию. У ионийцев повествование, рассказ о прошлом именовали логосом (logos). Лишь спустя время, уже в трудах основоположников философии логос приобрел современное значение - мысль, идея. И Геродот, и Фукидид понимали историю как осмысление хода событий прошлого, необходимое для «наставлений в образе жизни» тем, кто живет в настоящем. Пройдя испытание временем, историзм укрепил свои позиции, стал идейной базой культурной памяти. Н.А. Бердяев утверждал: «От первых дней Творения...человек находится в историческом, и историческое находится в человеке. Погружение в глубь времен есть погружение внутрь себя». ${ }^{1}$

Прошлое растворяется во времени, оставляя нам, наряду с памятью о былом, думы о настоящем и ответственность за будущее. Новое всегда относительно. Гете был прав, говоря, что все умное уже известно, надо только еще раз это продумать.

История - клад идей, золотая жила для мыслящего человека, чем бы он ни занимался. Различное отношение к истории есть совокупный результат действия двух причин: первая толкование времени, вторая - себя во времени. В дохристианский период истории время трактовали циклически, представляя его как сумму повторяющихся замкнутых на себя циклов. С христианством взгляд на время поменялся. Время предстало в качестве восхождения к бесконечному, разделившись на конечное земное и бесконечное внеземное. Противоположение циклического и внециклического рассмотрения времени характерно для теологической теории. Нас оно не интересует, впрочем, как и свойства времени в их абстрактном виде.

После Г. Гегеля и К. Маркса актуально не представление о чем-то вообще, а погружение в конкретно-предметное, либо конкретноисторическое состояние того, что оказывается объектом исследования. В случае со временем, актуально анализировать не столько его универсальные свойства, определять, куда и как оно движется. Важно то, что все существующее во времени может состояться, только соответствуя этим объективным характеристикам времени. Существовать во времени, значит обладать свойствами времени. Данное положение 


\begin{tabular}{|c|c|c|c|c|c|c|}
\hline \multirow{4}{*}{ Impact Factor: } & ISRA (India) & $=3.117$ & SIS (USA) & $=0.912$ & ICV (Poland) & $=6.630$ \\
\hline & ISI (Dubai, UAE & $=0.829$ & РИНЦ (Russia) & $=0.156$ & PIF (India) & $=1.940$ \\
\hline & GIF (Australia) & $=0.564$ & ESJI (KZ) & $=\mathbf{5 . 0 1 5}$ & IBI (India) & $=4.260$ \\
\hline & JIF & $=1.500$ & SJIF (Morocco) & $=5.667$ & OAJI (USA) & $=0.350$ \\
\hline
\end{tabular}

универсально и для бесконечного многообразия отдельных явлений, и для необходимо Л. Бердяев Н. Смысл истории. М. Мысль. 1990, с 14 присущих им признаком бытия, к которым принадлежат «качество» и «количество».

Стандартное понимание закона перехода количественных изменений в качественные упрощает взгляд на их связь. И Г.Гегель, и Ф.Энгельс были далеки от того смысла, который распространялся под прикрытием диалектической теории развития. Количество в качество не переходит непосредственно. Новое качество, качественное состояние возникает как переход из предшествующего качества. В изменившихся количественных условиях мера исчерпывает резерв устойчивости функционирования.

Мера - «качественное количество», она указывает на пределы изменения количества без существенных последствий для данного качества явления. Выход количественных показателей, необходимых для достигнутого качества, за границы меры неизбежно влечет качественные преобразования. Одновременно с потерей прежнего качества идет процесс рождения из него, на его основе нового качества, соразмерного изменившемуся количеству. Ключевое положение во взаимоотношениях качества с количеством занимает мера. О мере же специалисты по качеству предпочитают всерьез не рассуждать, сводя меру к количественным стандартам. Будто мера - это какое-то проходное состояние системы «качество-количество». Надо четко понимать объективную и функциональную роль меры в управлении, как качеством, так и количеством.

«Мера» не принадлежит ни качеству, ни количеству. Она выражает системный способ отношений качества и количества, связывает их. Итак, первое: количество и качество взаимодействуют через меру, мера опосредует их связь. Какую «выгоду» извлечет из настоящего заключения специалист-практик? Массовое производство, включая «рачительную» его разновидность, требует мерной характеристики, в противном случае сказочный сюжет о горшке с кашей или «цветике-семицветике» вполне имеет шанс реального продолжения. Китайский ширпотреб - классический пример разрушения диалектического единства в системе «количество-качество».

Рынок, по сути своей, не способен быть контролером меры, регулирующей отношения в системе «количество - качество». С приобретением оптовых форм развития, господствующего положения финансового капитала и его естественного порождения масштабных спекуляций и посредничества, современный рынок противопоставил себя производству и потерял интерес к состоянию производства. Рынок, используя специфику массового производства, насытился в меру своей извращенности и может позволить себе задавать качественные характеристики товаров.

Государство ведет себя на рынке, будто воспитатель в детском саду. Интересы рынка оно ставит выше интересов производителей и массового потребителя. Под «крышей» генеральной идеи - рынок тянет за собой производство, идет срастание рынка и государства. Качество-количественные оценки оказываются оттиснутыми в зону субъективного произвола.

До тех пор, пока теория качества системно не выстроена, теория управления качеством будет строиться на эмпирических началах, которые не в состоянии охватить предмет управления в целом, и относительно значимы в ограниченной специфике производства. За неимением ничего лучшего ими пользуются, экстраполируя локальный опыт на другие условия, получают эффект за счет добавленных мер по адаптации, к сожалению, опять-таки временный и частичный.

В калейдоскопе истории смены способов управления качеством можно различить определенную логику. Жизнь же требует не «определенной» логики, а логической определенности в форме целостной, системно обоснованной теории качества в качестве методологической опоры построения универсальных принципов теории управления качеством. Исходной здесь должна быть идея системности отношений «качество-количество» в рамках меры их сосуществования.

Раскрыться в полной мере качеству помогает количество. Качественную вещь можно создать и в одном экземпляре, но, чтобы раскрыться качественному потенциалу производителя, единственного экземпляра (или произведения) явно недостаточно. Фирма Фаберже обеспечила себе известность уже первым брендовым изделием, но брендом сделалась за счет последующих успехов в создании коллекции.

Примером системного понимания качества в рамках меры - мерностной определенности служат мелкие серии, выпуск коллекционных монет, медалей. Качество фиксируется в границах количественной величины, служащей мерой его выражения. Дело здесь не только в обеспечении условий преференции для vipпотребителя продукции. Значима также зависимость объективных признаков качества от количества произведенных экземпляров. Массовое производство объективно сопряжено со снижением качества продукции. Мера - 


\begin{tabular}{|c|c|c|c|c|c|c|}
\hline \multirow{4}{*}{ Impact Factor: } & ISRA (India) & $=3.117$ & SIS (USA) & $=0.912$ & ICV (Poland) & $=6.630$ \\
\hline & ISI (Dubai, UAE & $=0.829$ & РИНЦ (Russia & $=0.156$ & PIF (India) & $=1.940$ \\
\hline & GIF (Australia) & $=0.564$ & ESJI (KZ) & $=\mathbf{5 . 0 1 5}$ & IBI (India) & $=4.260$ \\
\hline & JIF & $=1.500$ & SJIF (Morocco & $=5.667$ & OAJI (USA) & $=0.350$ \\
\hline
\end{tabular}

пограничная служба качества, переход за мерное количество есть преступление против качества.

Массовый отечественный производитель вряд ли интересуется теорией качества. Она для него не актуальна. Если все же случайно кто-то наткнется на наши рассуждения, то, вероятнее всего, улыбнется их наивности. Пытаться с помощью теории перестроить российский рынок, придать ему цивилизованный вид - классическое донкихотство. Сначала надо организовать рыночное пространство посредством политической воли, законодательных инициатив и действенного, а не бутафорского контроля за узаконенным порядком, вернуть на рынок производителя товара, убрав немереное количество посредников - спекулянтов.

Настоящий производитель не заинтересован в спекулятивных операциях. Ему для устойчивого развития необходим свой потребитель, который, кстати, в свою очередь, совсем не против иметь своего определенного и доступного производителя в рамках нравственно - правовых отношений.

Чувство национального достоинства воспитывается историей и существующей реальностью. В школе можно учиться по самому лучшему учебнику истории, но кроме школьных уроков истории есть текущая жизнь, впечатляющая сильнее исторических экскурсов. На Востоке говорят: «сколько раз не повторяй халва, во рту сладко не будет». Теория всегда считалась лучшим практическим руководством, правда, в нормализованных обстоятельствах деятельности. Уходя в нелегальное и полулегальное положение, производитель отчуждается от качества и, естественно, от теории качества. Далее происходит подмена качества псевдокачеством и растут затраты на рекламную бутафорию.

Качество действительно предполагает серьезные затраты, но оно гарантирует устойчивую рыночную позицию. Работая на качество, производитель создает уверенность в своем и национальном будущем. Правильно выстроенное понимание качества гарантирует перспективу даже в условиях отечественного полурынка.

Постараемся в порядке введения в теорию качества сформулировать практически значимые фундаментальные положения:

- Качество не сводится к сумме важных для бытия товара свойств; оно - их своеобразная комбинация, выстроенная на базе обычно двух признаков - более общего и более специфического. К примеру. Обувь - «одежда для ног», шляпа - «одежда для головы», кашне «одежда для носа и шеи» и т.п. Следовательно, центральное внимание нужно уделить именно им.
- Качество допускает изменения, не ведущие к утрате качества, но снижающие или повышающие его потребительскую ценность; качество - совокупность качественных состояний, удовлетворяющих в разной степени системообразующим признакам. «Люфт» качества позволяет маневрировать в процессе создания продукта с заданным качеством в зависимости от конкретных возможностей производителя и потребителя.

- Качество не существует вне количества, они - диалектические противоположности, их противопоставление действительно только в пределах единства, из чего следует, что, создавая качество, необходимо закладывать в качественные характеристики количественное выражение как в отношении отдельных свойств товара, так и количества товарных изделий. А.К. Саврасов, оказавшись в тяжелой жизненной ситуации, сделал несколько копий своей знаменитой картины «Грачи прилетели». Как правило, авторские копии имеют высокий уровень мастерства и за них хорошо платят. Заплатили и художнику. Когда же задали вопрос П. Третьякову: купил бы он копию Саврасова, случить что с оригиналом? Ответ Третьякова оказался прогнозируемым по категоричности нет! Качество требует не только мастерства, но и вдохновения. Вдохновение с повторами выгорает. Качество всегда количественно, а количество - качественно.

- Качество и количество связывает мера, о которой чаще всего забывают. Между тем, определяя качество, нужно одновременно думать о его мерности, и с позиции рыночной конъектуры, и с точки зрения самих признаков качественности. «Качество» конкретизируется в представлении о «качественности». «Качество» понятие, отражающее модельный образ товара, «качественность» - определяет количественные пределы действительности и разумности качества (физического и морального статуса товара).

- Качество и представление о качестве относятся к явлениям устойчивым, однако время изменяет и их. Первоначально качество отождествляли со значением. Критериями качества были полезность и величина предмета, отношения. $\mathrm{C}$ развитием сознания и практических возможностей сложились основания сравнения и выбора. Качество относительно обособляется от количества. Совершается дифференциация полезности, переосмысливается участие в качестве количественных признаков. Эволюция понимания качества непосредственно обусловлена воплощением в деятельность творческого потенциала. Расхождение в интенсивности продвижения вперед индивидуального мастерства, интересов тех, кто 


\begin{tabular}{|c|c|c|c|c|c|c|}
\hline \multirow{4}{*}{ Impact Factor: } & ISRA (India) & $=3.117$ & SIS (USA) & $=0.912$ & ICV (Poland) & $=6.630$ \\
\hline & ISI (Dubai, UAE & $=0.829$ & РИНЦ (Russia & $=0.156$ & PIF (India) & $=1.940$ \\
\hline & GIF (Australia) & $=0.564$ & ESJI (KZ) & $=\mathbf{5 . 0 1 5}$ & IBI (India) & $=4.260$ \\
\hline & JIF & $=1.500$ & SJIF (Morocco & $=5.667$ & OAJI (USA) & $=0.350$ \\
\hline
\end{tabular}

призван расчищать путь таланта и массового сознания усложняет понимание качества и процесс управления качеством. Особое значение приобретает конкретность толкования качества, в частности, такого его базового признака, как объективность. Общественная теория бытия выстраивается на естественно-исторической основе - канву ее заложила природа, а исторический рисунок сотворил человек. В естественной среде все признаки, включая и такие синтетические, как качество - продукты стихийного движения. В обществе всякое явление проходит через деятельность, включает в себя и в свое качество мыслительный и физический труд человека. Определение качества явлений, созданных человеческой деятельностью, невозможно без социокультурной конкретизации. В связи с чем, актуализируются два вопроса:

- в каком статусе и в какой мере сознание входит в то, что традиционно принято называть качеством вещей (с услугами ясности больше)?

Ответы на оба вопроса надо искать в философской теории отчуждения. Теория отчуждения прямого отношения к теории качества не имеет. В ней ключи к методологии построения теории качества.

Из выше расположенных рассуждений понятно, что авторы - не идеалисты, скорее балансируют на грани пессимизма и оптимизма. Они критично воспринимают современный прагматизированный подход либераловрыночников к научной и философски обоснованной теории. Облегченный вариант теории, когда вырванный из общей теории фрагмент превращают в самую теорию и подгоняют под конструкцию извращенного в угоду спекулянтам рынка, экономистовтеоретиков и поставщиков качественного суррогата на отечественные прилавки устраивает. Как долго российская экономика сохранит подобную конфигурацию, нам (и не только нам) знать не дано, однако мировой опыт экономического развития на различных стадиях экономических отношений свидетельствует, что переходные периоды проходят и со временем экономическая жизнь приходит в нормальное состояние.

Траектория процесса отчуждения творчества человека в то, что существует вне его, должна с необходимостью сохранять и активировать способность к созиданию. В отличие от бытия природы, бытие человека не субстанционально. Оно не самодостаточно и может иметь место исключительно благодаря взаимообмену изначально с природой, в последствие с обществом, через которое выстраиваются человеческие отношения друг к другу и взаимодействие с природой. Инструмент, обеспечивающий бытие человека - труд, высшее качество труда проявляется в деятельности.

Качественность деятельности, с одной стороны, показатель качества жизни человека (так должно быть!), с другой - качественная деятельность встраивается в качество того, что он преобразует. Качество «первой» (естественной) природы формируется само по себе как совокупность объективно связанных естественных признаков, стихийно. Качество «второй» (реконструированной, приспособленной человеком под свои интересы) природы синтетическое. Оно представляется двойной спиралью, образуемой естественными признаками природного материала (возможно - в отношениях людей, знаниях, выраженных опосредованно) и качественными характеристиками человеческой деятельности знаниями, эмоциями, волей, ценностной ориентацией, мастерством. В итоге качество продукта в отличие от самого продукта воплощает качество личности.

Личность отчуждается в качестве и потому, в принципе, отчуждение естественно и не угнетает личность. Негативное следствие отчуждения вызвано непропорциональностью возмещения утраченной энергии деятельности. Обнаружив некачественность товара, скрытый брак производства, обманные действия продавца, нормальный покупатель расстраивается, в первую очередь, из-за собственного некачественного решения. Иные убытки сделки чаще всего возмещаются. Остается ощущение несовершенства собственного вкуса и знаний.

Качество всего, что создано деятельностью, включает свойства деятельности, как практической, так и духовной в объективированном (предметном либо функциональном) выражении. Отсюда следует вывод о необходимости формировать и направлять развитие способности массового сознания к качественной оценке товаров: определенный опыт в советское время был и показал свою действенность: «кружки», «школы», «университеты», в том числе инициируемые телевидением и радио. Место системного просвещения массового потребителя, профессиональной помощи в развитии культуры качественной избирательности, сегодня в эфире забито агрессивной рекламой, качество которой не контролируется или контроль не соразмерим с размером обмана. Кто должен быть главным просветителем? Производитель и только он, ибо лишь ему в полной мере, по логике становления понимания, следует знать, что такое качество. Браться за производство товара, не осмыслив конкретность качества данного изделия, означает профессиональный провал на рынке. Выпуск же продукта с бутафорским качеством преследуется 


\begin{tabular}{|c|c|c|c|c|c|c|}
\hline \multirow{4}{*}{ Impact Factor: } & ISRA (India) & $=3.117$ & SIS (USA) & $=0.912$ & ICV (Poland) & $=6.630$ \\
\hline & ISI (Dubai, UAE & $=0.829$ & РИНЦ (Russia) & $=0.156$ & PIF (India) & $=1.940$ \\
\hline & GIF (Australia) & $=0.564$ & ESJI (KZ) & $=5.015$ & IBI (India) & $=4.260$ \\
\hline & JIF & $=1.500$ & SJIF (Morocco) & $=5.667$ & OAJI (USA) & $=0.350$ \\
\hline
\end{tabular}

законом, правда, формально и постфактум. На последнее и надеются поставщики псевдокачественных товаров.

Объективности ради скажем: истинные творцы качественной продукции будут на нашем рынке изгоями до той поры, пока блюстители порядка уверенны в собственной безнаказанности за коррупционную деятельность. Тем не менее, идти вперед необходимо. История уродливо, но все-таки движется к порядку.

Вступление в ВТО качественной продукции нам не добавит и цены на качественные товары не снизит. Реальная перспектива связана с организацией единого экономического пространства в пределах Таможенного союза. Появляется перекрестный контроль за качеством, ослабляется влияние на рынок национальных корруптированных сил. Что же касается возможности роста межнационального криминального противодействия, то опасность существует, но разные условия организации криминала и межкриминальная конкуренция должны задержать деградацию рынка - главной причины на пути качественных национальных товаров, да и сам рынок, каким бы он не был, расширится, упростятся процедуры доступа к нему.

Давайте честно признаемся - проблема качества теоретически остается разработанной односторонне, что не очень заметно, потому что отсутствует нормальная организация производства и сбыта качественной товарной продукции. Нынешнюю практику удовлетворяет такая степень определенности в теории качества. Теория управления качеством упрощена до концепции контроля за условиями качественного производства. В то время как нет системности понимания, что такое качество товара? Производством заправляет рынок. На рынке правят спекулянты - посредники. Государство стремиться минимизировать свою экономическую функцию до сбора налогов. Реальной деятельности, направленной на придание рынку цивилизованной формы «куплипродажи» на принципах действительной свободы конкуренции нет. За признаками, обязательными для качества, надзор ограничен до уровня практической бесполезности. Рынок диктует порядок местным и региональным органам управления. Директор магазина управлял оборонным ведомством. Культура производителя и потребителя мало кого интересует, не до них. А ведь порядок внешний начинается с порядка внутреннего, с осознания «политического момента», обусловленного экономическим положением.

Исторически понимание качества и конкретности его реальности, представленной в товаре, отражают экономическое и культурное развитие общества. Качество во времена цехового производства определялось консервативностью техники изготовления, но и в тот период муниципальные власти жестко проверяли качество изделий, равно как и способности кандидата в производители, действовало официальное положение, одобренное властью города или страны. Сельхозпродукция контролировалась самими потребителями.

Промышленная революция упростила процесс производства, создала условия массового производства. Потребовались адекватные меры контроля качества. По мере выравнивания социальной архитектоники и большей доступности к ассортименту товаров, менялись представления о качестве в направлении его качественности - качественных составляющих. Одновременно формировалась возможность фальсификации качества. Дальше и де-факто, и де-юре, оставался всего шаг до подмены брендовых качеств. Переход за границу меры открывает дорогу правовым нарушениям и нравственному кризису, вплоть до беспредела.

Тенденции в толковании качества и отношении к качеству, сложившиеся в экономике массового производства, были неизбежными? Нет, они порождались новым характером производства, отражали этот характер и в известной степени являлись объективным отражением, но, кроме предмета, отражаемого сознанием, существует ракурс отражения, обусловленный позицией сознания отражающего субъекта, его интересами в качестве участника процессов, происходящих в объективной реальности.

Сама объективная реальность, по определению, располагается вне и не зависимо от сознания. Субъективируется ее отражение, что, в общем, выглядит в согласии с теорией отражения. Однако допускает, в частном порядке, и субъективное искажение - непроизвольное - по недопониманию, и сознательное с целью получения временного выигрыша. Конкуренция всегда борьба, к сожалению, борьба не всегда ведется по правилам.

Качество было и остается предметом манипуляции в интересах тех, кто управляет рынком. Консенсус о качестве создателя, производителя, продавца и потребителя - самая сладкая сказка. Согласие достижимо между творцом, потребителем и производителем. В данной «троице» воплощен субъектный механизм разрешения проблемы отчуждения. Творец создатель продукта находит удовлетворение в производстве и потреблении. Он реализует в них свою человеческую силу. Производитель заинтересован в устойчивых отношениях с творцом и потребителем. Потребитель 


\begin{tabular}{|c|c|c|c|c|c|c|}
\hline \multirow{4}{*}{ Impact Factor: } & ISRA (India) & $=3.117$ & SIS (USA) & $=0.912$ & ICV (Poland) & $=6.630$ \\
\hline & ISI (Dubai, UAE & $=0.829$ & РИНЦ (Russia) & $=0.156$ & PIF (India) & $=1.940$ \\
\hline & GIF (Australia) & $=0.564$ & ESJI (KZ) & $=\mathbf{5 . 0 1 5}$ & IBI (India) & $=4.260$ \\
\hline & JIF & $=1.500$ & SJIF (Morocco) & $=5.667$ & OAJI (USA) & $=0.350$ \\
\hline
\end{tabular}

удовлетворен качеством и соразмерностью цены. «Акции» и «sale» его не путают и не обманывают.

На пути к консенсусу встает продавец, тот субъект отношений, который, по-существу, к качеству товара не имеет никакого отношения, но именно он - ключевая фигура в рыночном хозяйстве. Мы у него приобретаем все необходимое. Он - монополист и как таковой диктует условия отношений через ценовой интерес и размер прибыли. В Новосибирске за двадцать лет не появилось ни одного брендового предприятия легкой промышленности, напротив, объявилась масса торговых брендов. Торговые ряды множатся, а потребителя уверяют, что производство товара нерентабельно. Культуру организации торговли подменяют понятием «качество продажи». Культура торговли измеряется ассортиментом, ценовой и физической доступностью товара, качественным консультативным сопровождением, отсутствием очередей, соблюдением санитарно-гигиенических норм, внешним видом и поведением персонала, сервисным обслуживанием. «Качество торговли» определяется соразмерностью цены и качества товара, соответствием продаваемого товара его сертификату, демонстрацией товара. Размер прибыли продавца не должен превышать величину прибыли производителя. Обоим нужно не ждать повышения покупательской активности только за счет увеличения зарплат потребителей, а создавать режим наибольшего благоприятствования для покупателя (не вступая в сговор с еще одним хищником рынка банками).

Только в России и только либералы рыночники при каждой возможности вспоминают, как плохо было народу до наступления подлинной демократии - голодали, ходили оборванцами, жили неизвестно где и как. Мониторинг качества жизни - через качественные возможности потребления целесообразен в рамках существующего времени. Критерий один - растет потребительская корзина и за счет чего она увеличивается?

Размер инфляции - необходимый, но не достаточный показатель состояния качества жизни. Правительство за основной ориентир взяло снижение инфляции. Показатель на самом деле социально-экономически значимый, свидетельствует о культуре рынка и опосредованно о состоянии производства. Минус этого показателя - отсутствие в нем качества. Качество жизни определяется через количество потребляемой продукции в денежном выражении. Качественный состав остается постоянным и о качественности можно лишь домысливать, так как качественность размывает качество. Качественность обуви, одежды, круп, рыбы, овощей, фруктов в пределах общего названия весьма существенно разнится. Резерв манипулирования качеством значителен. Главное все же в понимании качества, не название, а системная характеристика продукта, отражающая ассортимент, его изменение и динамику пропорционального представительства составляющих совокупность товаров.
Качество представляет
систему существенных для товара свойств - это банально и общеизвестно, чем активно пользуются. Подменяя свойства либо их системность в качественном продукте. Существенные свойства - те, которые не просто присущи товару, они обусловливают его функциональность. Подобные свойства, как правило, раскрываются в процессе «работы» товара по назначению, они скрыты от непрофессионального взгляда потребителя. В «чистом» виде рынок - посредник и к качеству изделий не должен иметь интереса. Задача рынка в теории организации товарного производства организация обмена между производителем и потребителем. Развитие рынка стимулирует наращивание производства в интересах потребителя в пределах инфраструктурного статуса рынка.

Монополизация производства привела к накоплению финансового капитала, автономизации последнего и контролю за рынком. В результате рынок из посредника превратился в ключевого субъекта, индикаторную функцию - показывать востребованность товаров - пытается подменить ролью организатора экономической деятельности в целом, что извращает систему экономики.

Экономику товарного производства создали производство продукта и потребность в массовом продукте. Системообразующим фактором здесь является производство товара в качестве продукта, необходимого для потребления другими, то есть процесс отчуждения потребления. При натуральном производстве качество продукта вряд ли было актуальной проблемой. Качество «растворялось» в консерватизме техники и технологии, традиционности ассортимента. Вопрос о качестве поднял потребитель, когда на ярмарке получил возможность сравнивать. Рынок, выросший из ярмарочных сходов, представительский статус постепенно обогатил рекламным бизнесом, взяв в управление отношения производителя и потребителя. Рычаги управления - финансовая политика, направления - основные - два: влияние на количество и качество.

Качество продукта обрело актуальность в товарном производстве. Стало ясно, что в понимании качества присутствуют чувственное и рациональное мышление (последнее в форме расчета). Субъективный фактор объективируется 


\begin{tabular}{|c|c|c|c|c|c|c|}
\hline \multirow{4}{*}{ Impact Factor: } & ISRA (India) & $=3.117$ & SIS (USA) & $=0.912$ & ICV (Poland) & $=6.630$ \\
\hline & ISI (Dubai, UAE & $=0.829$ & РИНЦ (Russia) & $=0.156$ & PIF (India) & $=1.940$ \\
\hline & GIF (Australia) & $=0.564$ & ESJI (KZ) & $=\mathbf{5 . 0 1 5}$ & IBI (India) & $=4.260$ \\
\hline & JIF & $=1.500$ & SJIF (Morocco) & $=5.667$ & OAJI (USA) & $=0.350$ \\
\hline
\end{tabular}

и фетишизируется. На объективные свойства товара рынок непосредственно (с помощью собственных механизмов) воздействовать не способен, зато на объективизацию субъективных представлений, очень даже может. Так манипуляция качеством сначала включалась в функции рынка, потом стала элементом экономической политики. [14]

Здравая и здоровая экономическая политика призвана работать над совершенствованием качества в двух взаимосвязанных направлениях: технико-технологическом, достроенным жестким правовым блоком обеспечения, и социокультурном - оказывать всестороннюю поддержку становлению условий субъективного восприятия качества, блокировать негативный эффект рекламного воздействия, давно и основательно ставшего атрибутом рыночных спекуляций на значимости качества для покупателя. Наличие выбора и платежеспособных возможностей не служат основанием бесспорности качественного приобретения.

На существующем рынке цена и качество разведены даже на аукционах, славящихся тщательностью организационной культуры. Покупателя превращают в эксперта и эта гримаса рынка не столь плоха, как нелогична. Рынок заставляет потребителя развиваться в качестве личности. Из обывателя с кошельком мы, чтобы не оказаться лохами, невольно стараемся больше узнать о предмете интереса, повышаем свою «покупательскую квалификацию». Термин не новый, им пользуются журналисты, но для них он проходной, вербальный номер, а для нас уже не новое сочетание расхожих слов, а важнейшее понятие, без которого современная теория качества не имеет системного целостного вида.

«Покупательская квалификация» включает, наряду с определенными знаниями, помогающими определить местоположение магазина, диапазон цен на товар, требует наличия основных сведений о производителе, качественных признаках товара, рыночной репутации производителя, традиций фирмы, масштабов деятельности. Сегодня на потребительском рынке наивный покупатель рискует сверх всякой позволяющей меры оказаться жертвой не только обмана, но и собственной беспечности, следовательно, без каких-либо прав на компенсацию.

Покупатель в России защищен формально. В реальной жизни приходится руководствоваться знаменитым правилом «спасение утопающих («покупающих») - дело рук самих утопающих, читай «покупающих». Повышение «покупательской квалификации», при наличии желания, для государства взаимовыгодное дело, активизирующее культурное национальное наследство и патриотическое настроение массового потребителя. Хотя есть и путь иной, испытанный при Мао в Китае - «чем хуже, тем лучше».

Импортный ширпотреб - не китайский - в 1980-90-е гг. был у нас на ура! Впечатляли ассортимент, упаковка, внешние признаки продукта. И что в итоге? Спустя 10 лет производитель возвращает советские бренды, естественно в отсутствии действенного контроля, не советского качества.

Мы умеем делать качественные изделия и вполне в состоянии вернуть себе «наш» рынок. Вопрос даже не в цене, проблема в потере контроля за потребительским (и не только потребительским, судя по сбоям в ракетной технике, эксплуатации авиатехники и т.п.) рынком. Нам объясняют: нужны экономические меры. Правильно, однако, это полуправда. Если нужны, то принимайте. У власти должна быть власть не номинальная. Пришло время понять, что экономика всегда была политикой, экономическая теория - политической экономией.

Экономическое движение есть самодвижение, но оно не в вакууме происходит. Экономика - основа общественного движения. Общество обеспечивает условия экономического движения, и государство вправе энергично включаться в механизмы экономического самодвижения, направляя развитие экономики в интересах общества.

Удивительное дело. Когда речь заходит о будущем технического прогресса, то футурологи разных мастей стонут, что автономизация движения техники приведет к господству роботов над человеком, а в развитие экономики лучше не вмешиваться. Для кого лучше? Вывод напрашивается один: не нарушать самодвижение экономики в интересах тех, кто приватизировал экономику и на чьей службе находятся «пограничники», запрещающие контролировать экономические процессы посредством политики.

Ни одна из конвертируемых валют не обеспечена качественным товарным эквивалентом и «свободное» движение валюты продолжается под прикрытием политики. Финансовое самодвижение создает благоприятные возможности для хаоса на потребительском рынке. Государство вяло защищает законные интересы национального производителя, даже тогда, когда товар - продукт межнациональной интеграции. Нет политической агрессивности, политика тащится в обозе экономики вместо то, чтобы опережать ее развитие на базе объективных социальноэкономических тенденций. Хочется верить объяснениям политиков относительно длительности вступления в ВТО. Хорошо, что 


\begin{tabular}{|c|c|c|c|c|c|c|}
\hline \multirow{4}{*}{ Impact Factor: } & ISRA (India) & $=3.117$ & SIS (USA) & $=0.912$ & ICV (Poland) & $=6.630$ \\
\hline & ISI (Dubai, UAE & $=0.829$ & РИНЦ (Russia) & $=0.156$ & PIF (India) & $=1.940$ \\
\hline & GIF (Australia) & $=0.564$ & ESJI (KZ) & $=\mathbf{5 . 0 1 5}$ & IBI (India) & $=4.260$ \\
\hline & JIF & $=1.500$ & SJIF (Morocco) & $=5.667$ & OAJI (USA) & $=0.350$ \\
\hline
\end{tabular}

они торговались, создавая правовую «подушку безопасности» для отечественного производителя товаров массового потребления. Проблема: как они уступками со стороны ВТО воспользуются?

Время для политического действия - не решений - самое благоприятное. Дурман девяностых и нулевых как будто пошел на спад. Возвращается осознание качественного преимущества многих советских продуктов легкой и пищевой промышленности. Наблюдается оживление в потребкооперации, что способно стимулировать производство сельхозпродуктов на селе. Растет недоверие к потребительскому импорту, в том числе и по причине его массового китайского производства. Стабилизируются миграционные потоки.

Жесткая оценка социально-экономической ситуации и прямое указание на ответственность правительства за неисполнение президентских поручений 2012г. в Послании В.В. Путина, ассоциируются с решимостью «закручивать гайки», чтобы движение шло по намеченному курсу. Явная активизация в межнациональных экономических отношениях внутри Таможенного союза, перезагрузка стратегических отношений с акцентом на Китай, Индию, Иран, Латинскую Америку. Реальная возможность полномасштабного сотрудничества с Египтом, Сирией и тем же Ираном - ключевыми государствами Ближнего Востока и африканского севера - все это уникальная международная сфера для восстановления баланса на внутреннем рынке потребительских товаров.

Отечественным производителям нужна «внятная» экономическая политика. Под «внятностью» они понимают: ясность, последовательность, гарантийное сопровождение, позволяющее отсечь многоликий произвол административных органов и «блюстителей» порядка. За качество отвечают все. И те, кто производит, и те, кто призван обеспечивать права производителей. Таможенный Союз зажег зеленый свет на пути национальных товаров на рынке стран Договора. Тем самым создана равновесная реальная рыночная конкуренция, позволяющая оценивать натуральное, а не рекламное качество. Кстати, замечательная тема исследования - «качество реальное и «рекламное», т.е. создаваемое рекламой.

Не менее актуально и проанализировать проблему качества в системе координат национального менталитета и межнациональной интеграции. Интеграция сознательно подменяется глобализацией, несмотря на очевидность в различии этих явлений. Обе тенденции объективны и характерны для новейшей истории.
Интеграция

взаимопроникновени

деятельности социально - экономического и культурно-гуманитарного масштаба. Она может иметь межнациональный размер, пример «Союзное государство (РФ и РБ); локальный Таможенный Союз; региональный (Шанхайская организация, ЕЭС). Глобализация указывает на всемирный масштаб явления. $\mathrm{K}$ числу глобальных проблем относятся те, которые возникли как следствие общих, но не обязательно интеграционных, процессов, и требуют консолидированного решения.

Глобальные проблемы, в отличие от проблем, связанных с интеграцией, актуальны потенциально, носят стратегический смысл. К примеру, как защитить жизнь на Земле от крупных метеоритов. Когда время наступления события отложено, но само оно сверх актуально по значимости, то в образовавшийся зазор активно устремляются спекулянты, в том числе финансовые олигархи, пытаясь извлечь прибыть из неопределенности.

Качество связано с глобализацией, но практически не так актуально. С интеграцией же качество связано самым непосредственным образом.

Рассмотрим проблему «качества потребительского товара» в системе координат «национальное» и «межнациональное». Прежде всего, надо найти ответ на вопрос: способна ли интеграция вытеснить национальную составляющую качества?

Интеграционные процессы строятся на стандартизации и единых метрологических характеристиках производства, что соответствует объективной реальности. Технический прогресс опирается на науку, научные знания императивны в части нормативности. Однако бытие общего не самодостаточно. Общие требования реализуются через особенное развитие, обусловленное конкретностью обстоятельств действия. Иными словами, как бы стандартизировано производство товара не было, все равно в нем проявится своеобразие условий производства.

Конкретность условий - региональных, национальных имманентно присутствует в сырье, климате, традициях, культуре сознания исполнителей. И во всем этом сила производства, определяющая нюансы качества товара, создающие особый к нему интерес потребителя. Чай выращивают в наше время по всему миру, но уникальность чайных плантаций в Шри-Ланке, национального отношения к чаю, обеспечили качеству цейлонского продукта лидирующие позиции. Тоже самое можно сказать о кенийском кофе, болгарском и чилийском перце, французских коньяках и шампанском, 


\begin{tabular}{|c|c|c|c|c|c|c|}
\hline \multirow{4}{*}{ Impact Factor } & ISRA (India) & 3.117 & SIS (USA) & $=0.912$ & ICV (Poland) & $=6.630$ \\
\hline & ISI (Dubai, UAE & $=0.829$ & РИНЦ (Russia) & $=0.156$ & PIF (India) & 1.940 \\
\hline & GIF (Australia) & $=0.564$ & ESJI (KZ) & $=\mathbf{5 . 0 1 5}$ & IBI (India) & $=4.260$ \\
\hline & JIF & $=1.500$ & SJIF (Mor & $=5.667$ & OAJI (USA) & $=0.350$ \\
\hline
\end{tabular}

украинском сале, баварском и голландском пиве, шотландских виски, российском льне, египетском хлопке, китайском шелке, аргентинской коже, греческом оливковом масле и многом еще. Конкретностью среды следует дорожить и обеспечивать преференции ее воспроизводства. В основополагающих договорах, регулирующих отношения в Единой Европе, четко прописан приоритет национальных традиций.

Таможенный Союз закрепляет межнациональное разделение труда, выстроенное в XX столетии, способствует выражению объективных и субъективных сторон развития производства, взаимно обогащает рынок, облегчая доступ к нему производителей. Но все это - теория. Теория же перерастает в разумную практику не только потому, что она правильная. Практикой теорию делает деятельность, причем, чтобы получить искомый результат, деятельность должна быть системной и последовательной.

Интерес к качеству товара, теоретически должен начинаться не в производстве. Его исходная позиция на нормализованном рынке, точнее на встрече производителя и покупателя. Нормальный рынок - индикатор качества товара. Спрос тянет за собою производственную цепочку. Но не стихийный спрос брошенных на произвол судьбы покупателей. Спрос - состояние сознания, обусловленное покупательской способностью, однако не сводимое только к количеству денег, тем более, когда кредитование всячески стимулируется банками. Спрос, отданный на откуп посредникам, лоббистам, спекулянтам - смертельная болезнь для национального производителя России. Спрос следует брать под контроль и формировать, покупателя нужно воспитывать. Воспитание потребителя стоит немало. Но оно этого стоит, если смотреть в будущее.

Рыночный либерализм соответствовал расцвету экономики массового производства первого типа, ориентированной на обеспечение свободного доступа и выбора товаров. Подобное производство воспринимает потребителя как абстрактного субъекта отношения в системе «производитель - продавец - покупатель». Продавцу отводится роль активного посредника, но не более того. Он культурно обеспечивает место встречи производителя с потребителем. Система же должна быть функционально активной, что предполагает не присутствие образующих ее компонентов, а их соучастие. Совершенство системы определяется не эстетичностью - признаком конструкции. Оно проявляется в максимальной активизации возможностей того, системой отношений чего она выступает. Совершенство конструкции системы - в предельной реализации потенциала отношений, создающих системность.
Покупатель совершенен как субъект системного взаимодействия своей покупательской подготовкой. Он совершенен не размером платежной способности. Его соучастие определяется знанием товарно-экономической ситуации. Потребитель - не объект приложения действий продавца и производителя. Потребитель - субъект рынка и в его (и других субъектов тоже) интересах быть информированным не рекламным сообществом, а профессиональными источниками. Тогда контрафакт и «лохизм» перестанут заселять рынок. Качество товара начинается в сознании потребителя. Навязывать представление о качестве - плохо для всех законных субъектов экономических отношений. Его нужно воспитывать опять-таки всеми: производителем, продавцом, самим покупателем и институтами гражданского общества, если государство пассивно.

Переход к массовому производству второго типа - «умной», «рачительной» экономике активирует системные отношения. В новом свете предстает функция рынка. Вместе с производителем, продавец ориентируется на знание потребительских вкусов. К совершенству системы остается сделать всего один, однако не простой, шаг - всем миром взяться за формирование потребительской культуры.

Обвинение нынешнего поколения в потребительском отношении к жизни не совсем справедливо. Потребление - конечная цель производства. Беда - в отсутствии потребительской культуры массового потребителя, беда действительно социокультурного размера. Еще одно последствие финансирования культурного прогресса. Почему одна власть сменяет другую, а культура по-прежнему у власти последняя в очереди на политическую актуальность? Время понять, что не только наука превратилась в непосредственную производительную силу. Культура - также фактор развития производства, причем фактор многогранный и, весьма эффективный.

\section{Заключение}

Одной из задач в системе повышения конкурентоспособности региона - выявить потенциал кластеризации региона. Традиции обувной отрасли в регионах ЮФО, СКФО и тенденции ее развития дают шанс на успех в случае взаимодействия всех участников процесса поставщиков, производителей, представителей власти, торговых и сервисных компаний. Первый шаг на пути к такому взаимодействию необходимо сделать в ходе обмена мнений и разъяснения взаимных позиций. Однозначно воспринимают ли участники обувного рынка области те проблемы, которые перед ними стоят? Каков вектор 


\begin{tabular}{|c|c|c|c|c|c|c|}
\hline \multirow{4}{*}{ Impact Factor: } & ISRA (India) & $=3.117$ & SIS (USA) & $=0.912$ & ICV (Poland) & $=6.630$ \\
\hline & ISI (Dubai, UAE & $=0.829$ & РИНЦ (Russia) & $=0.156$ & PIF (India) & $=1.940$ \\
\hline & GIF (Australia) & $=0.564$ & ESJI (KZ) & $=\mathbf{5 . 0 1 5}$ & IBI (India) & $=4.260$ \\
\hline & JIF & $=1.500$ & SJIF (Morocco) & $=5.667$ & OAJI (USA) & $=0.350$ \\
\hline
\end{tabular}

структурных изменений на российском кожевеннообувном рынке - к развитию или стагнации отрасли? Каковы условия и реальные возможности для развития конкурентоспособного производства в регионе? Какой должны быть поддержка власти на федеральном и региональном уровне? Можно ли в современных условиях делать ставку на взаимодействие и сотрудничество как на реальный фактор конкурентоспособности? Как решить проблему подготовки и закрепления кадров на производстве?

Для обувного бизнеса тема формирования регионального кластера весьма актуальна. Создание кластеров - один из самых эффективных инструментов повышения конкурентоспособности территорий. Необходимость кластерного подхода к управлению конкурентоспособностью предприятий, который состоит в разработке новой промышленной политики стимулирования организации и развития кластеров на основе формирования отношений сетевого сотрудничества и государственно-частного партнерства (кластерной политики) и включает исследование кластеров, кластерную стратегию и методы еe обеспечения являются палочкой выручалочкой на сегодня. С точки зрения проиесса управления кластерный подход рассматривается как совокупность этапов и мероприятий по организации кластеров и их развитию, т.е. кластеризации. Такой подход позволит малым и средним предприятиям легкой промышленности успешно конкурировать не только на внутреннем, но и на международном рынке [17-18].

Роль региональной и местной власти в запуске и координации кластерных проектов очень важна, в связи с этим удалось сформировать эффективный механизм представления интересов бизнеса во взаимоотношениях с властью. Предложен элемент, выполняющий функцию «координатора и коммуникатора». Для развития этого элемента нужен предметный диалог, основанный на взаимном доверии и заинтересованности, прежде всего, между самими субъектами отрасли, - в этом заинтересованы и власть, и бизнес. Необходимо разработать совместные предложения по направлениям, формам и методам государственной поддержки развития отраслевого кластера, а именно:

- осуществление нового строительства, расширения и реконструкции производственных мощностей, объектов жилищного, социальнокультурного назначения, коммунального хозяйства и бытового обслуживания населения, административного управления, министерства чрезвычайных ситуаций, охраны окружающей среды и экологической безопасности на региональном уровне;

- coдействие

B

повышении

конкурентоспособности продукции промышленных предприятий и ее продвижении на внутреннем и внешнем рынке;

- организация и осуществление проектов в области производства программных средств;

- обновление материально-технической базы производств кластера, внедрение новых технологий;

- сохранение и развитие накопленного потенциала в сфере науки и научного обслуживания; совершенствование механизмов финансирования науки; реализация научных результатов в производственной и социальной сфере региона;

- достижение качества образования, соответствующего государственному образовательному стандарту; осуществление регионального заказа на предоставление услуг дополнительного образования; достижение динамичного баланса между рынком труда и подготовкой профессиональных кадров; развитие высшего и среднего профессионального образования.

Предложен комплекс мер по антикризисному управлению легкой промышленностью, включая следующие приоритетные направления:

- повымение конкурентоспособности предприятий легкой промышленности;

- развитие отраслевых информационных услуг; продолжение модернизации основных фондов;

- смягчение недостатка оборотных средств;

- повышение

эффективности

государственного управления;

- расшивка неплатежей.

- Сформирован план мероприятий по реализации антикризисной программы в легкой промышленности, включая:

- нормативно-правовое и научнометодическое обеспечение антикризисной деятельности;

- развитие

антикризисной инфраструктуры поддержки предприятий легкой промышленности;

- расширение деловых возможностей предприятий легкой промышленности;

- финансовые механизмы поддержки и развития антикризисной деятельности предприятий легкой промышленности;

- развитие межрегионального и международного сотрудничества предприятий легкой промышленности в антикризисной сфере.

Для дальнейшего совершенствования нормативно-правового регулирования 


\begin{tabular}{|c|c|c|c|c|c|c|}
\hline \multirow{4}{*}{ Impact Factor: } & ISRA (India) & $=3.117$ & SIS (USA) & $=0.912$ & ICV (Poland) & $=6.630$ \\
\hline & ISI (Dubai, UAE & $=0.829$ & РИНЦ (Russia) & $=0.156$ & PIF (India) & $=1.940$ \\
\hline & GIF (Australia) & $=0.564$ & ESJI (KZ) & $=\mathbf{5 . 0 1 5}$ & IBI (India) & $=4.260$ \\
\hline & JIF & $=1.500$ & SJIF (Morocco) & $=5.667$ & OAJI (USA) & $=0.350$ \\
\hline
\end{tabular}

антикризисной деятельности представляется целесообразным формирование плана мероприятий по реализации антикризисной программы в легкой промышленности, а именно:

- конкретизация и детализация целей устойчивого развития предприятий легкой промышленности должна быть построена в рамках линии развития промышленного сектора экономики, которая базируется на структурных преобразованиях экономики и внедрении антикризисных технологий развития производства и экспорта товаров народного потребления. В рамках развития можно выделить три этапа, сроки которых представлены достаточно условно и могут быть скорректированы в процессе реализации устойчивого развития предприятий легкой промышленности:

- 2009-2012 гг. -

Антикризисное развитие, предусматривающее преодоление кризисных явлений и восстановление кризисных потерь предприятий легкой промышленности и изыскание ресурсов для последующей модернизационной трансформации легкой промышленности

- 2013-2015 гг. - Инвестиционное обновление основных средств предприятий легкой промышленности, в том числе качественное повышение конкурентоспособности.

- 2016-2020 гг. - Инновационное развитие - начало массового освоения новых видов оборудования и технологий, переход к экспансии на зарубежные рынки товаров легкой промышленности.

Использование разработанных и предлагаемых методических положений по повышению конкурентоспособности региона на основе теории кластера позволит принимать решение о привлечении и рациональном размещении инвестиционных средств, направленных на реализацию необходимых мероприятий по повышению эффективности деятельности субъектов привлекательного кластера и росту их конкурентоспособности.

Для решения поставленной задачи предложен конкурентоспособный ассортимент мужской, женской и детской обуви с учетом факторов, влияющих на потребительский спрос: соответствие основным тенденциям моды с учетом экономических, социальных и климатических особенностей регионов ЮФО и СКФО. В рамках разработанной стратегии будет организовано

конкурентоспособной производство использованием современных механизированных инновационных техпроцессов. Кроме того, будет предусмотрено производство обуви для удовлетворения спроса элитного потребителя с использованием большей доли ручного труда, чтобы придать обуви целевую направленность и высокую востребованность.

Для реализации разработанного ассортимента мужской, женской и детской обуви предложены инновационные технологические процессы её производства с использованием современного технологического оборудования на базе передовых нанотехнологий, формирующие основу для снижения затрат на обувь и, тем самым, повышающие ее конкурентоспособность в сравнении с аналогичным ассортиментом обуви ведущих мировых фирм, с возможностью широкоассортиментного выпуска обуви не только по видам, но и по методам крепления, что придаст ей востребованность и повышенную конкурентоспособность. Предложены компоновки технологического оборудования, которые представляют возможность формировать технологический процесс как для производства мужской, так и детской обуви в объемах, которые определяются имеющимися у регионов производственными площадями и используемыми формами организации производства, но конечно с учетом спроса для обеспечения её реализации в полном объеме.

При этом финансовое благополучие и устойчивость вновь создаваемых предприятий в регионах ЮФО и СКФО во многом зависит от притока денежных средств, обеспечивающих покрытие взятых ими обязательств. Отсутствие минимально-необходимого запаса денежных средств может спровоцировать для предприятий финансовые затруднения. В свою очередь и избыток денежных средств может быть знаком того, что предприятие терпит убытки. Причина этих убытков может быть связана как с инфляцией и обесцениванием денег, так и с упущенной возможностью их выгодного размещения и получения дополнительного дохода. В любом случае именно постоянный анализ денежных потоков позволит предприятию контролировать свое реальное финансовое состояние и предупреждать от банкротства.

Денежные потоки от финансовой деятельности в большой степени формируются при выработке схемы финансирования и в процессе расчета эффективности инвестиционного проекта.

Если изготовленная обувь будет реализована не полностью, предприятие теряет часть прибыли, которая необходима для дальнейшего развития производства. Для снижения убытков производитель должен иметь ежедневные сведения о реализации продукции и принимать эффективные решения, а именно: или своевременно изменять цены на изготавливаемый ассортимент обуви, или же, что более эффективно и оправданно, приступать к производству нового, более востребованного на 


\begin{tabular}{|c|c|c|c|c|c|c|}
\hline \multirow{4}{*}{ Impact Factor: } & ISRA (India) & $=3.117$ & SIS (USA) & $=0.912$ & ICV (Poland) & $=6.630$ \\
\hline & ISI (Dubai, UAE & $=0.829$ & РИНЦ (Russia) & $=0.156$ & PIF (India) & $=1.940$ \\
\hline & GIF (Australia) & $=0.564$ & ESJI (KZ) & $=5.015$ & IBI (India) & $=4.260$ \\
\hline & JIF & $=1.500$ & SJIF (Morocco) & $=5.667$ & OAJI (USA) & $=0.350$ \\
\hline
\end{tabular}

рынке ассортимента обуви.

Менеджеры по продажам или маркетологи, контролирующие процесс продажи конкретно выпускаемого ассортимента обуви, ежедневно должны рассчитывать поступление денежных средств от своей операционной деятельности. В результате отслеживания за поступлением денежных средств будем иметь информацию об их чистом притоке от своей операционной деятельности. Уменьшение объема продаж приведет к снижению денежного потока и потребует снижение отпускной цены изделия с целью повышения объема продаж. Если такое мероприятие не приводит к увеличению денежного потока, то необходимо принимать своевременное решение о целесообразности дальнейшего выпуска этого ассортимента обуви.

Для данного расчета важным является дифференциация данных, участвующих в расчете. Для расчета себестоимости конкретной выпускаемой модели исходными данными являются постоянные и переменные затраты, которые зависят от производственного оборудования, состава основных и вспомогательных материалов, численности работников и др.

Основными исходными данными, которые используются в процессе мониторинга, являются отпускная цена единицы продукции и объем продаж.

Таким образом, расчет может выполняться ежедневно или в выбираемом временном диапазоне, при этом, задавая только объем продаж и цену единицы изделия за определенный период, будем получать приращение денежного потока за этот период.

Расчеты проводятся на основе оценки степени выполнения и динамики производства и реализации продукции, определении влияния факторов на изменение величины этих показателей, выявлении внутрихозяйственных резервов и разработке мероприятий по их снижению, которые должны быть направлены на ускорение оборачиваемости продукции и уменьшение потерь, что позволит достичь значительного экономического эффекта.

Большое значение в управлении выпуском продукции имеет оценка фактического выпуска и реализации в пределах производственной мощности, то есть в границах «минимальный максимальный» объем производства. Сопоставление с минимальным, безубыточным объемом позволяет определить степень, или зону «безопасности» организации и при отрицательном значении «безопасности» снять с производства отдельные виды продукции, изменить условия производства и тем самым снизить расходы или прекратить производство данной продукции.
Сравнение достигнутого объема выпуска с максимальным объемом, определяемым производственным потенциалом организации, позволяет оценить возможности роста прибыли при увеличении объемов производства, если увеличится спрос или доля объема реализации обуви на рынке.

Для обувного предприятия, стремящегося к прочному положению на рынке, установление цены обуви для реализации имеет ключевое значение для успеха избранной стратегии. Цена является инструментом стимулирования спроса и одновременно представляет собой главный фактор долгосрочной рентабельности его деятельности.

В связи с этим необходимо проводить анализ безубыточности.

Рассмотрены различные соотношения объемов реализации и цен на выпускаемую продукцию. Снижение цен происходит, когда предприятие в целях увеличения объемов продаж использует систему скидок. Данное мероприятие приводит к увеличению выручки от реализации и получению дополнительной прибыли. Однако область дохода не является неограниченной - при достижении некоторого объема производства дальнейшее его расширение становится экономически невыгодным.

Эффективность всех этих мероприятий при создании кластера возможна лишь при активном взаимодействии ветвей власти и обязательно при поддержке на федеральном уровне - ЮФО и СКФО могут полностью или частично разгрузить обувщиков от инфраструктурных затрат при создании новых производств в рамках кластера. А решить вопросы налоговых преференций может только федерация; закрыть границы для серого и чёрного импорта - опять компетенция Москвы, учитывая что отрасль находится в тяжелом депрессивном состоянии, что для изменений в лучшую сторону нужен очень мощный набор инструментов и властные решения и совместные действия всех заинтересованных сторон.

Быть может, сейчас, когда донские обувщики видят, насколько быстро их ряды редеют под давлением конкуренции, готовность к совместным действиям будет выше. В противном случае Ростов уже очень скоро перестанет быть обувной столицей юга России. Наконец, институционально-организационньй сценарий предполагает ответ на вопрос, как должен быть организован кластер, как он должен формироваться и выращиваться? Для нас кластер предполагает соорганизацию как минимум четырёх крупных технологических групп, которые образуют технологическую основу кластера: 


\begin{tabular}{|c|c|c|c|c|c|c|}
\hline \multirow{4}{*}{ Impact Factor: } & ISRA (India) & $=3.117$ & SIS (USA) & $=0.912$ & ICV (Poland) & $=6.630$ \\
\hline & ISI (Dubai, UAE & $=0.829$ & РИНЦ (Russia & $=0.156$ & PIF (India) & $=1.940$ \\
\hline & GIF (Australia) & $=0.564$ & ESJI (KZ) & $=\mathbf{5 . 0 1 5}$ & IBI (India) & $=4.260$ \\
\hline & JIF & $=1.500$ & SJIF (Morocco & $=5.667$ & OAJI (USA) & $=0.350$ \\
\hline
\end{tabular}

- $\quad$ прорывные научные лаборатории опытные производства, на которых создаются основы новых технологий;

- разработческие центры, на базе которых будут создаваться макеты и образцы технологий для опробывания на экспериментальных производствах;

- промышленно-технологические группы, способные осуществлять оснастку производства для изготовления опытных серий;

- маркетинговые группы, способные продвигать новый тип продукции на рынок и формировать устойчивых спрос.

- Управленческой

надстройкой, обеспечивающей взаимосвязь этих четырех крупных технологических групп друг с другом, могут быть:

- $\quad$ Совет инвесторов, который принимает решение о приоритетном финансирования того или иного проекта;

- $\quad$ экспертный Совет, рассматривающий различные проекты по мере их подготовки к реализации;

- $\quad$ креативный иентр, подготавливающий материалы для принятия решений экспертным советом и советом инвесторов.

Достижение цели в области развития кластеров возможно только при проведении комплексной технологической модернизации реального сектора экономики региона. Применительно к ЮФО и СКФО она возможна только при учете интересов всех участвующих хозяйствующих субъектов. Речь идет о таких направлениях, как:

- увеличение доли инновационного сектора и внедрение технологических инноваций на предприятиях, образующих кластеры;

- развитие предпринимательской деятельности в области крупного, среднего и малого бизнеса и взаимное сотрудничество в целях внедрения инноваций, что ведет к расширению действующих и созданию новых кластеров;

- усиление связей и взаимозависимости предприятий промышленности и научноисследовательских и образовательных центров и школ;

- совершенствование территориального размещения промышленных предприятий.

В заключение рассмотрения процесса формирования и реализации кластерной политики в регионе укажем, что это - сложная задача, разработка и реализация которой должна носить научный характер. Ее успех зависит от множества факторов и условий, и центральное место здесь принадлежит научным принципам управления и стремлению к динамичному развитию региона, заинтересованности всех ветвей власти, как муниципальных и региональных, так и федеральных ветвей власти.

Тем не менее, наиболее слабым местом предприятий является низкий уровень информационного обеспечения именно технологической подготовки производства. Это объясняется тем, что автоматизированные системы ТПП специализированы и зависят от характера производства, вида выпускаемой продукции, серийности их выпуска. Кроме того, прикладное программное обеспечение АСТПП неоднородно по назначению, оно формируется из набора продуктов, каждый из которых обеспечивает разработку отдельного вида технологических процессов.

Поэтому возникает необходимость в создании информационного обеспечения в виде универсальной базы данных, с целью снижения трудоемкости и повышения эффективности работ на этапе технологической подготовки производства за счет их использования.

Для технологического процесса сборки обуви клеевого метода крепления авторами создано информационное обеспечение, целью которого является формирование паспорта модели и автоматизированный выбор технологического процесса.

Для создания информационного обеспечения авторами выполнены следующие задачи:

- выделены критерии, определяющие структуру технологического процесса сборки обуви клеевого метода крепления на основе методов априорного ранжирования и ранговой корреляции;

- разработан классификатор и структурная схема кодирования модели обуви для автоматизированного проектирования технологического процесса;

- составлена матрица совпадений технологических операций в зависимости от конструкции, материалов и способов обработки заготовок верха, стелечных и подошвенных узлов, каблуков и промежуточных деталей для объективного обоснования порядка составления схемы технологического процесса и алгоритма его выбора;

- разработана структурно-логическая модель сборки обуви клеевого метода крепления на основе принципов системного подхода, обеспечивающая выработку оптимальных технологических решений;

- разработана информационная поддержка для автоматизированного проектирования технологического процесса сборки обуви в виде совокупности баз данных, которые содержат сведения о различных вариантах выполнения одних и тех же технологических операций в 


\begin{tabular}{|c|c|c|c|c|c|c|}
\hline \multirow{4}{*}{ Impact Factor: } & ISRA (India) & $=3.117$ & SIS (USA) & $=0.912$ & ICV (Poland) & $=6.630$ \\
\hline & ISI (Dubai, UAE & $=0.829$ & РИНЦ (Russia & $=0.156$ & PIF (India) & $=1.940$ \\
\hline & GIF (Australia) & $=0.564$ & ESJI (KZ) & $=\mathbf{5 . 0 1 5}$ & IBI (India) & $=4.260$ \\
\hline & JIF & $=1.500$ & SJIF (Morocco & $=5.667$ & OAJI (USA) & $=0.350$ \\
\hline
\end{tabular}

зависимости от оснащенности и мощности предприятия;

- построен алгоритм работы программы, в соответствии с которым формируются точные предписания, определяющие вычислительный процесс, ведущий от варьируемых начальных данных к исходному результату;

- разработано программное обеспечение, позволяющее формировать технологический процесс сборки обуви клеевого метода крепления с одновременным определением трудоемкости и количества рабочих для производства заданного количества моделей.

Разработанное программное обеспечение соответствует основным показателям качества информационных систем, таких как:

- гибкость - способность к адаптации и дальнейшему развитию, возможность приспособления информационной системы к новым условиям, новым потребностям предприятия;

- надежность - функционирование без искажения информации, потери данных по «техническим причинам» за счет создания резервных копий хранимой информации, выполнения операций протоколирования, поддержания качества каналов связи и физических носителей информации, использования современных программных и аппаратных средств;

- эффективность - возможность решать возложенные на нее задачи в минимальные сроки, обеспечивается оптимизацией данных и методов их обработки, применением оригинальных разработок, идей, методов проектирования и подтверждается его способностью минимально зависеть от ресурсов оборудования: процессорного времени, пространства, занимаемого во внутренней и внешней памяти, пропускной способности, используемой в устройствах связи;

- безопасность - свойство системы, в силу которого посторонние лица не имеют доступа к информационным ресурсам организации, обеспечивается настройкой параметров запуска таким образом, что пользователь, запустив приложение, видит только главную кнопочную форму и такое меню и панель инструментов, при котором он не может воспользоваться кнопками, предназначенными для разработчика приложения.

Программное обеспечение в соответствии с алгоритмом обрабатывает выбранные условия и выдает на печать готовый вариант техпроцесса на данную модель обуви с расчетом трудоемкости и количества рабочих, а также паспорт модели. При использовании разработанного информационного обеспечения задача технолога по формированию технологического процесса сводится к выбору конструктивных признаков модели и основных ограничений, к которым относятся производственная мощность, наличие оборудования, производственных площадей; анализу результатов; корректировке выбранных условий (в случае необходимости) и выбору оптимального варианта технологического процесса.

Что касается эффективности внедрения информационного обеспечения, любое предприятие может быть оценено с различных сторон, а именно: экономической, финансовой, организационной, временной, экологической, социальной.

Результат расчетов по любому отдельно примененному методу оценки эффективности предложенного решения способен отразить лишь часть их положительных сторон. Между тем, числовые значения возможных к использованию различных критериев могут значительно различаться, а иногда и находиться в конфликте. В такой ситуации оправдано использование синергетической (комплексной) оценки эффективности решений, которые предполагают определение преимуществ не по одному критерию, а по совокупности критериев.

Эффективность от внедрения представленного информационного обеспечения может быть оценена с двух сторон: социальной и экономической.

Социальный эффект от внедрения информационного обеспечения для автоматизированного проектирования технологического процесса заключается в следующем:

1. В результате внедрения в учебный процесс - повышение уровня подготовки специалистов за счет применения инновационных технологий в образовании.

2. В результате внедрения в производство изменение характера и улучшение условий труда, ресурсная оснащенность трудовой деятельности, повышение профессионализма, увеличение средней продолжительности свободного от «бумажной работы» времени технолога.

Оценка экономической эффективности внедрения информационных технологий зачастую происходит либо на уровне интуиции, либо вообще не производится. С одной стороны, это вызвано нежеланием поставщиков решений тратить значительные усилия на проведение подробного предварительного анализа, с другой стороны, вероятно, присутствует значительная доля недоверия потребителей к получаемым результатам таких исследований. Однако, обе эти проблемы проистекают из одного источника, а именно - отсутствия понятных и надежных методик оценки экономической эффективности ИТ проектов.

Полная экономическая эффективность 


\begin{tabular}{|c|c|c|c|c|c|c|}
\hline \multirow{4}{*}{ Impact Factor: } & ISRA (India) & $=3.117$ & SIS (USA) & $=0.912$ & ICV (Poland) & $=6.630$ \\
\hline & ISI (Dubai, UAE & $=0.829$ & РИНЦ (Russia) & $=0.156$ & PIF (India) & $=1.940$ \\
\hline & GIF (Australia) & $=0.564$ & ESJI (KZ) & $=\mathbf{5 . 0 1 5}$ & IBI (India) & $=4.260$ \\
\hline & JIF & $=1.500$ & SJIF (Morocco) & $=5.667$ & OAJI (USA) & $=0.350$ \\
\hline
\end{tabular}

использования программного обеспечения для автоматизированного проектирования ТПП состоит из экономии в сфере технологической подготовки производства, которая является следствием повышения производительности труда технологов за счет автоматизированного выбора перечня технологических операций с расчетом трудоемкости и количества рабочих.

В сфере производства экономию получают благодаря выбору оптимального технологического процесса вследствие типизации и унификации принимаемых технологических решений. Кроме того, значительно сокращаются сроки подготовки производства, а этот фактор трудно переоценить в наше время, когда конкурентоспособности можно добиться только при часто изменяющемся ассортименте выпускаемой продукции, а для этого необходимо добиться хороших техникоэкономических показателей работы предприятия.

Эти и другие преимущества автоматизированного выбора технологических процессов, хотя многие из них и сложно определить путем прямых экономических расчетов, способствуют существенному улучшению показателей работы обувных предприятий.

Полученные результаты позволяют говорить о достижении синергетического эффекта как с точки зрения технологии (за счет значительного сокращения времени на технологическую подготовку производства, выбора оптимального технологического процесса, сокращения переналадок технологического процесса при смене ассортимента, выбора правильной последовательности запуска образцов), так и с точки зрения эффективности производства в целом, за счет одновременного достижения социального и экономического эффекта.

Сегодня от предприятия легкой промышленности, стремящегося не просто выжить, но и развиваться, требуется умение не просто грамотно эксплуатировать имеющиеся технологии, но в первую очередь, активно позиционировать себя на рынке, поставляя в короткие сроки качественную, удовлетворяющую требованиям, запросы и ожидания потребителей, продукцию по минимальной цене. Иными словами в настоящее время выживет тот, кто быстрее других выпустит на рынок продукцию, наиболее полно соответствующую требованиям потребителей, обеспечив при этом минимальную себестоимость ее производства.

Что должно предпринять предприятие, чтобы перечисленные показатели стали его конкурентными преимуществами?

1. Понимать не только текущие, но и будущие предпочтения клиентов и уметь разрабатывать виды продукции, соответствующие этим предпочтениям.
2. Обеспечить настройку технологических процессов производства, гарантирующую их минимальную себестоимость за счет идентификации и исключения всех видов издержек, не приносящих ценности продукции.

3. Вывести продукцию на рынок быстрее, чем это сделают конкуренты.

Реализация перечисленных задач будет зависеть от того, насколько отлажено и эффективно будут работать на предприятии все подразделения.

Каким образом можно обеспечить эту отлаженную и эффективную работу? С нашей точки зрения, посредством

- посредством определения совокупности процессов или видов деятельности, обеспечивающих производство продукции с характеристиками качества, удовлетворяющими требования, запросы и ожидания потребителей;

- установления между процессами четкого и понятного взаимодействия;

- определения целей в области качества на уровне предприятия и подразделений, обеспечивающих понимание тех результатов, которые должны быть достигнуты подразделениями, и которые обеспечивают достижение общих целей предприятия;

- планирования ресурсов, необходимых для достижения целей;

- определения процедур, обеспечивающих выполнение работ в подразделениях наиболее эффективным способом;

- измерения результатов и сравнения их с поставленными целями;

- анализа и принятия решений о том, что следует улучшить в рамках каждого подразделения.

Таким образом, представлена совокупность процессов, за счет функционирования которых формируется система управления предприятием, ориентирующая его на производство продукции, соответствующей по своим характеристикам требованиям, запросам и ожиданиям потребителей и настраивающая все виды деятельности, связанные с обеспечением производства на показатель эффективности, а именно:

- выстраивается система идентификации источников издержек, и разработки адекватных мер по их снижению,

- формируются достоверные данные, демонстрирующие эффективность использования вложенных инвестиций, что может способствовать привлечению новых инвесторов;

- уменьшается себестоимость продукции, что дает возможность снижать цену, расширять рынок и увеличивать объемы производства; 


\begin{tabular}{|c|c|c|c|c|c|c|}
\hline \multirow{4}{*}{ Impact Factor: } & ISRA (India) & $=3.117$ & SIS (USA) & $=0.912$ & ICV (Poland) & $=6.630$ \\
\hline & ISI (Dubai, UAE & $=0.829$ & РИНЦ (Russia & $=0.156$ & PIF (India) & $=1.940$ \\
\hline & GIF (Australia) & $=0.564$ & ESJI (KZ) & $=\mathbf{5 . 0 1 5}$ & IBI (India) & $=4.260$ \\
\hline & JIF & $=1.500$ & SJIF (Morocco & $=5.667$ & OAJI (USA) & $=0.350$ \\
\hline
\end{tabular}

- происходит снижение издержек, обычно связаных с сокращением количества брака и других видов отходов, что положительно сказывается на таких показателях работы предприятия, как влияние на окружающую среду, состояние промышленной безопасности;

- формируется имидж социальноориентированного предприятия;

- выполняется четкая постановка целей и задач перед каждым сотрудником, определяющих результат, который должен быть получен при выполнении работы;

- определение ресурсов, необходимых для выполнения работы, и обеспечение ресурсами;

- обеспечение знаниями и навыками, необходимыми для понимания того, как следует выполнять работу, чтобы обеспечить ее максимальную эффективность;

- измерение результатов работы на уровне сотрудников, подразделений и организации в целом и сравнение результатов с целями;

- анализ результатов и адекватное реагирование на них через систему корректирующих и предупреждающих действий.

Как показывает практика, умение реализовать эти процессы на уровне высшего менеджмента создает условия, необходимые для формирования конкурентоспособного предприятия, то есть все это руководитель уже сегодня может взять на вооружение, чтобы обеспечить своим предприятиям эту самую экономическую стабильность.

Кроме того, важно, чтобы наименований продукции было не слишком много. Для большинства российских предприятий основной резерв оптимизации ассортимента до сих пор заложен в значительном сокращении ассортиментного ряда. Слишком большой ассортимент плохо сказывается на экономических показателях - появляется много позиций, которые по объемам продаж не могут выйти даже на уровень безубыточности. В итоге общая рентабельность сильно падает. Только исключение нерентабельных и малорентабельных позиций из ассортимента может дать компании увеличение общей рентабельности на 30-50 \%.

Кроме того, большой ассортимент распыляет силы предприятия, затрудняет грамотное предложение товара клиентам (даже сотрудники отдела продаж не всегда способны объяснить разницу между той или иной позицией или наименованием), рассеивает внимание конечных потребителей.

Здесь будет уместным напомнить о психологии восприятия информации человеком. Реальность такова, что среднестатистический человек способен единовременно воспринять не более 5-7 (реже до 9) смысловых конструктивных решений. Таким образом, человек, делая выбор, сначала выбирает эти самые 5-7 вариантов на основании такого же количества критериев. Если продавец предлагает большее количество критериев выбора, покупатель начинает испытывать дискомфорт и самостоятельно отсеивает незначимые, с его точки зрения, критерии. То же происходит и при выборе собственно товара. Теперь представьте, что происходит, если перед человеком сотня практически не отличимых (для него) товаров, а купить ему нужно один. Люди в такой ситуации ведут себя следующим образом: либо вообще отказываются от покупки, так как не в состоянии сопоставить такое количество вариантов, либо предпочитают то, что уже брали (или что кажется знакомым). Есть и еще одна категории людей (около 7\%), любители новинок, которые наоборот выберут что-то, что еще опробовано ими.

Таким образом, с точки зрения покупателя (для обеспечения спокойного выбора из поддающихся восприятию вариантов) ассортимент должен состоять не более чем из 5-7 групп по 5-7 наименованиям, т.е. весь ассортимент с точки зрения восприятия оптимально должен состоять из 25-50 наименований. Если наименований объективно больше, то выход состоит только в дополнительной классификации.

Считается общепринятым, что покупателю нужен широкий ассортимент. Этот самый широкий ассортимент часто обозначают даже как конкурентное преимущество. Но на деле получается, что для производителя широкий ассортимент - это сотни наименований продукции, а для потребителя - 7 наименований уже более чем достаточно. Таким образом потребителю нужен вовсе не широкий ассортимент, а необходимое для него разнообразие.

Это возможно, если будут реализованы составные части стратегии развития России до 2020 года, а именно: будет решена задача по переводу экономического развития России от инерционного энергетического сценария к альтернативному инновационному социально ориентированному типу развития, при формировании эффективной промышленной политики, для чего необходимо:

- разработать и законодательно закрепить основы эффективной государственной промышленной политики как системы согласованных целей, приоритетов и действий государственных органов, бизнеса и науки по повышению эффективности работы промышленности, обеспечению высокой конкурентоспособности продукции, товаров и услуг и неуклонного роста производства. При её формировании предусмотреть опережающий рост 


\begin{tabular}{|c|c|c|c|c|c|c|}
\hline \multirow{4}{*}{ Impact Factor: } & ISRA (India) & $=3.117$ & SIS (USA) & $=0.912$ & ICV (Poland) & $=6.630$ \\
\hline & ISI (Dubai, UAE & $=0.829$ & РИНЦ (Russia & $=0.156$ & PIF (India) & $=1.940$ \\
\hline & GIF (Australia) & $=0.564$ & ESJI (KZ) & $=\mathbf{5 . 0 1 5}$ & IBI (India) & $=4.260$ \\
\hline & JIF & $=1.500$ & SJIF (Morocco & $=5.667$ & OAJI (USA) & $=0.350$ \\
\hline
\end{tabular}

во всех отраслях высокотехнологичной продукции c увеличением её доли в общем объеме промышленного производства к 2020 году не менее $50 \%$, равенство субъектов промышленной политики, гарантии прав собственности;

- обеспечить реализацию особых мер поддержки приоритетных высокотехнологичных отраслей, чтобы создать условия для эффективного развития всей промышленности России;

Обеспечить увеличение объема инвестиций, создание экономических и правовых предпосылок для внедрения и использования высоких технологий и новых материалов, в первую очередь разрабатываемых в России, для этого следует:

- законодательно закрепить основы национальной инновационной системы в Российской Федерации; установить повышающий коэффициент на расходы на НИОКР, включаемые в себестоимость; снизить НДС до $12 \%$; освободить от налогообложения прибыль предприятий, инвестируемую в производство; создать институты долгосрочного кредитования модернизации и технического перевооружения промышленности под невысокий процент; усовершенствовать систему администрирования НДС, изменить порядок и сроки уплаты налогов для пополнения предприятиями промышленности собственных оборотных средств; осуществить переход на дифференцированную ставку налога на добычу полезных ископаемых в зависимости от природных условий, степени выработанности месторождений и т.д.;

- разработать и осуществить меры по борьбе с ценовым монополизмом, по стабилизации тарифов на услуги естественных монополий, подготовить и принять федеральный закон «О ценовой и тарифной политике»; содействовать созданию и продвижению отечественных национальных, региональных и корпоративных брендов отечественной продукции для развития конкурентоспособной среды с целью создания конкурентной продукции, для чего внедрить систему качества, содействовать реализации программ, направленных на выявление, независимую оценку качества и продвижение отечественной продукции, активизировать работы по стандартизации, включая затраты на научные исследования в этой сфере по разработке новых и корректировке существующих национальных стандартов;

- учитывать, что машиностроение является системообразующим комплексом, для чего обеспечить в сжатые сроки его модернизацию и восстановление технологической основы национального машиностроительного комплекса - станкостроения. В этих целях использовать как отечественные разработки, так и закупку зарубежной техники и технологий, используя международное разделение труда, шире задействовать механизм лизинга. Кроме общих мер поддержки промышленности, необходимо дополнительно подготовить и принять государственную стратегию развития станкоинструментальной промышленности на период до 2020 года, включая реализацию специальных целевых программ, направленных на финансирование перспективных научных разработок;

- модифицировать размеры и порядок взимания таможенных сборов для стимулирования импорта новейшего технологического оборудования при одновременном содействии возрождению отечественного производства такого оборудования, в частности, отменить таможенные пошлины и НДС на ввоз нового импортного технологического оборудования, не производимого в стране;

- разработать и принять комплекс специальных мер по обеспечению машиностроения и станкостроения научными и инженерными кадрами, высококвалифицированными рабочими, особенно в сфере научных исследований и прикладных разработок, сформировать систему трудоустройства молодых специалистов; разработать и принять поправки в Налоговый кодекс (гл. 25), устанавливающие режимы ускоренной амортизации и преференций (премий), позволяющих амортизировать активную часть основных фондов в объеме, превышающем их балансовую стоимость;

- принять меры по стимулированию системы государственного и коммерческого лизинга технологического оборудования в целях технического перевооружения отраслей машиностроения; рассмотреть возможность предварительной 100-процентной оплаты из средств федерального бюджета стоимости поставок предприятиям уникального импортного оборудования, в т. числе на лизинговой основе, необходимого для целей технического перевооружения машиностроения и станкостроения;

- ввести в практику проведение систематической всероссийской переписи металлообрабатывающего оборудования, что позволит иметь объективные данные о состоянии станочного парка машиностроительных предприятий;

- разработать и реализовать комплекс мер по решению проблемы недостатка квалифицированных кадров в промышленности, по повышению качества подготовки кадров в высших учебных заведениях, по обеспечению молодых специалистов жильем на льготных условиях, ввести в практику подготовку 


\begin{tabular}{|c|c|c|c|c|c|c|}
\hline \multirow{4}{*}{ Impact Factor: } & ISRA (India) & $=3.117$ & SIS (USA) & $=0.912$ & ICV (Poland) & $=6.630$ \\
\hline & ISI (Dubai, UAE & $=0.829$ & РИНЦ (Russia) & $=0.156$ & PIF (India) & $=1.940$ \\
\hline & GIF (Australia) & $=0.564$ & ESJI (KZ) & $=\mathbf{5 . 0 1 5}$ & IBI (India) & $=4.260$ \\
\hline & JIF & $=1.500$ & SJIF (Morocco) & $=5.667$ & OAJI (USA) & $=0.350$ \\
\hline
\end{tabular}

специалистов по государственному заказу, на основе частно-государственного партнёрства обеспечить современной техникой и общежитиями профессионально-технические училища, разрешить предприятиям средства, израсходованные на подготовку кадров относить на затраты производства в полном объёме, принять специальные законодательные и нормативные документы, направленные на обеспечение промышленное освоение Сибири и Дальнего Востока;

- разработать и законодательно закрепить комплекс мер, обеспечивающий заинтересованность хозяйствующих субъектов в активном участии в проектах повышения ресурсо- и энергоэффективности, включая элементы денежно-кредитной политики, валютного и инвестиционного регулирования, механизмы субсидирования, специальные налоговые и амортизационные режимы;

- реализовать комплекс мер, направленных на массовое развитие малых и средних предприятий в промышленно-производственной, инновационной сферах и в сфере услуг, в первую очередь, в части обеспечения малым и средним предприятиям доступа к производственным помещениям, закупки оборудования, в т. числе на лизинговой основе, развития микрофинансирования и кредитной кооперации;

- принять меры для создания российской перерабатывающей промышленности равных конкурентных условий с импортерами, ускорить разработку и принятие федерального закона «О торговле» и сопутствующих нормативных актов по организации эффективного функционирования российской оптовой и розничной торговли;

- разработать стратегию регионального промышленного развития субъектов РФ, в том числе территориального размещения производительных сил на долгосрочную перспективу, увязать развитие региональной инфраструктуры с размещением промышленных объектов;

- четко прописать систему реализации основополагающих целей государственной промышленной политики, обеспечивающих решение системных проблем реального сектора экономики, соотнести потребность в инвестициях, источники инвестиций и реально достижимые социально-экономические результаты.

В Стратегии развития легкой промышленности на период до 2020 года и плана мероприятий по еe реализации учтены национальные интересы России (повышение уровня и качества жизни населения, здоровья нации, стратегической и экономической безопасности государства), предложения субъектов Российской Федерации, общественных организаций и объединений о необходимых мерах поддержки отрасли по приоритетным направлениям ее развития.

В основу Стратегии был заложен переход легкой промышленности на инновационную модель развития. Особое внимание уделено вопросам защиты внутреннего рынка от теневого товарооборота, технического перевооружения и модернизации производства, импортозамещения и экспорта.

Сегодня легкая промышленность Российской Федерации - это важнейший многопрофильный и инновационнопривлекательный сектор экономики.

Вклад легкой промышленности в промышленное производство России сегодня составляет порядка 1 \% (в 1991 г. этот показатель был равен 11,9\% и соответствовал уровню развитых стран, таких как США Германия и Италия, которые на протяжении всех этих лет сохраняют этот показатель на уровне $8-12 \%$ ), в объеме экспорта - 1,3\%.

В настоящее время в легкой промышленности функционирует 14 тыс. крупных, средних и малых предприятий, расположенных в 72 регионах страны. Около 70 \% предприятий являются градообразующими. Среднесписочная численность промышленнопроизводственного персонала, занятого в отрасли, 462,8 тыс. человек, $75 \%$ которого составляют женщины. Научное обеспечение отрасли осуществляют 15 учебных, научно исследовательских и проектных институтов, многие разработки которых соответствуют и даже превышают мировой уровень.

Основными территориями размещения предприятий, определяющих промышленную и экономическую политику отрасли, являются Центральный (55 предприятий), Приволжский (30) и Южный (17) федеральные округа, которые имеют наибольший удельный вес в общем объеме производимой продукции и являются наиболее социально значимыми.

Результаты работы отрасли за 2017 г. показали, что она в условиях кризиса в состоянии нарастить объемы производства в подотраслях, ориентированных непосредственно на рынок. Следует отметить, что в условиях кризиса резко сужается ассортимент поставляемых в Россию товаров. Это дает отечественной легкой промышленности стратегические возможности для занятия освобождающихся ниш и упрочения своих позиций на рынке.

В 2017 г. оборот розничной торговли продукцией легкой промышленности составил 2,0 трлн руб., его доля в розничном товарообороте страны $14,5 \%$, а в розничном товарообороте непродовольственных товаров 26,3\%. По уровню потребления продукция легкой промышленности 


\begin{tabular}{|c|c|c|c|c|c|c|}
\hline \multirow{4}{*}{ Impact Factor: } & ISRA (India) & $=3.117$ & SIS (USA) & $=0.912$ & ICV (Poland) & $=6.630$ \\
\hline & ISI (Dubai, UAE & $=0.829$ & РИНЦ (Russia) & $=0.156$ & PIF (India) & $=1.940$ \\
\hline & GIF (Australia) & $=0.564$ & ESJI (KZ) & $=\mathbf{5 . 0 1 5}$ & IBI (India) & $=4.260$ \\
\hline & JIF & $=1.500$ & SJIF (Morocco) & $=5.667$ & OAJI (USA) & $=0.350$ \\
\hline
\end{tabular}

уступает только продовольственным товарам, намного опережая рынки бытовой электроники, легковых автомобилей и других товаров. С учетом макроэкономических показателей и тенденций развития рынок товаров легкой промышленности к 2020 г. может составить свыше 3,3 трлн руб.

Существующие преференции и решаемые в той или иной степени проблемы на федеральном и региональном уровнях пока недостаточны, чтобы устранить влияние негативных факторов на развитие отрасли и превратить ее в конкурентоспособный и саморазвивающийся сектор экономики, а отечественным производителям укрепить свои позиции на внутреннем рынке и на равных конкурировать на мировом рынке не только с производителями Китая, Турции, Индии и ряда других развивающихся стран, но и со странами ЕС и США.

Ситуацию в отрасли еще более усугубил мировой финансовый кризис. В условиях кризиса даже те предприятия, которые за последние годы добились положительных результатов в инновационном развитии, уделяя значительное внимание модернизации производства, уже вынуждены и будут вынуждены в ближайшие годы сокращать объемы производства и отказываться от долгосрочных вложений. Это обусловлено возникшими трудностями, связанными с привлечением банковских кредитов (доля заемных средств в оборотных средствах за последние годы достигла 40 \%), с одной стороны, увеличением объемов официального импорта, контрафактной и контрабандной продукции, падением спроса и замедлением реализации многих видов товаров потребительского и производственно-технического назначения, сокращением рабочих и специалистов - с другой стороны.[19]

Отсутствие кардинальных мер по решению выявленных проблем существенно скажется на экономике отрасли, еe технологическое отставание в обозримой перспективе может стать необратимым процессом, что приведет к деградации наукоемких производств, к усилению товарной зависимости от зарубежных стран, потери государства будут геометрически расти, что повысит стратегическую и национальную опасность России.

Изменить сложившуюся ситуацию можно, только разработав и реализовав антикризисные меры и мероприятия, направленные на подъем экономики легкой промышленности, придание ей новых импульсов в инновационном, социальном и региональном развитии, в повышении конкурентоспособности и эффективности производства на новом технико-технологическом уровне. Сегодня отрасль обеспечивает своей продукцией только четверть платежеспособного спроса населения, а мобилизационные потребности страны - всего лишь на 17-36\%, что противоречит закону о безопасности государства, согласно которому в объеме продукции стратегического назначения доля отечественной должна составлять не менее $51 \%$. Поэтому сегодня перед легкой промышленностью стоят новые вызовы и задачи, решение которых требует новых подходов не только на краткосрочную, но и на долгосрочную перспективу.

Это обусловило цель Стратегии создание условий для ускоренного инновационного развития легкой промышленности России, обеспечения эффективного соответствия объемов производства, качества и ассортимента продукции совокупному спросу потребителей, повышения национальной значимости отрасли и ее имиджа в мировом сообществе.

Цели и задачи Стратегии соответствуют проводимой политике государства в области инновационного и социально-экономического развития России в среднесрочной и долгосрочной перспективе. Стратегия призвана стать: одним из основных инструментов в решении проблем отрасли и взаимоувязать задачу ее экономического роста с обеспечением потребностей граждан страны, силовых структур и смежных отраслей в качественных и доступных потребительских товарах, в продукции технического и стратегического назначения.

Реализация Стратегии даст возможность легкой промышленности России стать индустриально развитой отраслью, которая будет обеспечивать работой многие тысячи людей, повышать благосостояние работающих, укреплять стратегическую и экономическую безопасность страны.

Главный результат Стратегии - это переход легкой промышленности на качественно новую модель инновационного, экономического и социального развития, основа которой - новая технологическая и научная база, новые методы управления производством, взаимосвязь науки, производства и бизнеса. Это обеспечение эффективного соответствия объемов производства, качества и ассортимента продукции совокупному спросу российского и мирового рынков.

В заключение ещё раз хотелось бы заострить внимание, что всё это станет реальностью, если будет реализовано одно условие, а именно, продукция легкой промышленности будет производиться высокого качества и с учётом интересов этого самого потребителя. 


\begin{tabular}{|c|c|c|c|c|c|c|}
\hline \multirow{4}{*}{ Impact Factor: } & ISRA (India) & $=3.117$ & SIS (USA) & $=0.912$ & ICV (Poland) & $=6.630$ \\
\hline & ISI (Dubai, UAE & $=0.829$ & РИНЦ (Russia) & $=0.156$ & PIF (India) & $=1.940$ \\
\hline & GIF (Australia) & $=0.564$ & ESJI (KZ) & $=\mathbf{5 . 0 1 5}$ & IBI (India) & $=4.260$ \\
\hline & JIF & $=1.500$ & SJIF (Morocco) & $=5.667$ & OAJI (USA) & $=0.350$ \\
\hline
\end{tabular}

References:

1. Prokhorov, V. T., et al. (2008). Quality management of competitive and in-demand materials and products. Monograph. under the General editorship of doctor of technical Sciences, Professor V. T. Prokhorov (Eds.). (p.654) Mine: Publishing house GOU VPO yurgues.

2. Prokhorov, V. T., et al. (2012). Managing production of competitive products in demand. under the General editorship of doctor of technical Sciences, Professor V. T. Prokhorov (Eds.). VPO yurgues. (p.280). Novocherkassk: yurgtu (NPI).

3. Prokhorov, V. T., et al. (2018). The competitiveness of enterprise and product competitiveness is the key to successful import substitution of goods demanded by consumers in the regions of SFD and NCFD. collective monograph. under the General editorship of Dr. sci. prof. V. T. Prokhorova (Eds.). Institute of service sector and entrepreneurship (branch) of don state technical University. (p.337). Novocherkassk: Lik.

4. Prokhorov, V. T., et al. (2017). The concept of import substitution of products of light industry: background, challenges, and innovations. monograph. under the General editorship of Dr. sci.prof. V. T. Prokhorova (Eds.). Institute of service sector and entrepreneurship (branch) of don state technical University. (p.334). Novocherkassk: Lik.

5. Golovko, A. V., et al. (2019). Quality management system-the basis of technical regulation for the production of importsubstitutable products. Monograph. In prof. V. T. Prokhorova (Eds.). Institute of service sector and entrepreneurship (branch) of don state technical University. (p.326). Novocherkassk: URGU (NPI).

6. (2015). GOST R ISO 9000-2015 quality management System. The main provisions and Glossary (Amendment)

7. (2015). GOST R ISO 9001-2015 quality management System. Requirements GOST R ISO 9001-2015 national standard of the Russian Federation quality management system date of introduction 2015-11-01

8. (n.d.). GOST R 57189-2016 / ISO / TS 9002:2016. National standard of the Russian Federation. Quality management system. Guidance on the application of ISO 9001:2015 (ISO/TS 9002:2016, IDT)" (app. By the order of Rosstandart on 25.10.2016 N 1499-St). [Official website of the International organization for standardization (ISO)] Retrieved January 22, 2019, from: http://www.iso.org/iso/ru/catalogue detail?csnu mber $=52844$

9. (2010). GOST R ISO 9004-2010. Managing for the sustained success of an organization. Quality management approach.

10. Prokhorov, V. T., Tikhonova, N. In., Aspen, T. M., Reva, V. D., Tartans, A. A., \& Kozachenko, P. N. (2014). On the impact of nanomaterials and technologies in injection molding properties of polymer compositions based on ethylene vinyl acetate. Vestnik Kazanskogo tekhnologicheskogo universiteta, Vol. 17, No. 19, 130-135.

11. Prokhorov, V. T., et al. (2015). About new opportunities of regions of SFD and skfo on formation of preferences by consumers of the production made at the enterprises of light industry. the monograph / on the General edition of doctor of technical Sciences, prof. V. T. Prokhorov (Eds.). In the sphere of service and business (Phil.) Fader. state budget. educated. institutions higher. professional education "don state technical. UN-t " in the Mine Growth. region. (Isoip (branch) DGTU). (p.316). Novocherkassk: URGU (NPI).

12. Prokhorov, V. T., et al. (2017). The concept of import substitution of products of light industry: background, challenges, and innovations: monograph. under the General editorship of Dr. sci. prof. V. T. Prokhorova (Eds.). Institute of service sector and entrepreneurship (branch) of don state technical University. (p.334). Mines: Isoip (branch) DSTU.

13. Prokhorov, V. T., et al. (2014). The quality revolution: through the ad or through a quality real: monograph. under the General editorship of doctor of technical Sciences, Professor V. T. Prokhorov (Eds.). VoIP (branch) of DSTU. (p.384). Novocherkassk: URGU (NPI).

14. (2018). Management of the real quality of products and not advertising through the behavior of the leader of the team of the enterprise of light industry: monograph / In prof. V. T. Prokhorova (Eds.). Institute of service sector and entrepreneurship (branch) of don state technical University. (p.384). Novocherkassk: URGU (NPI). 